*ak RMIS View/Frint Document Cover Sheet tow

This document was retrieved from the Documentation and Records Manaqement (DRM) ISEARCH System. It is intended for Information only and may not be the most recent or updated version. Contact a Document Service Center (see Hanford Info for locations) if you need additional retrieval information.

Accession \#: D196088846

Document \#: SD-WM-RPT-227

Title/Desc:

CHARACTERIZATION SAMPLING EQUIPMENT STATUS REPORT 01/1996 THRU 03/1996

Pages: 46 


\begin{tabular}{|c|c|}
\hline $\begin{array}{l}\text { APR } 301996 \text { (28) } \\
\text { Sta. } 4 \text { ENGINEERING DA }\end{array}$ & 1. EOT Pase 1 of $\frac{1}{15}$ \\
\hline
\end{tabular}

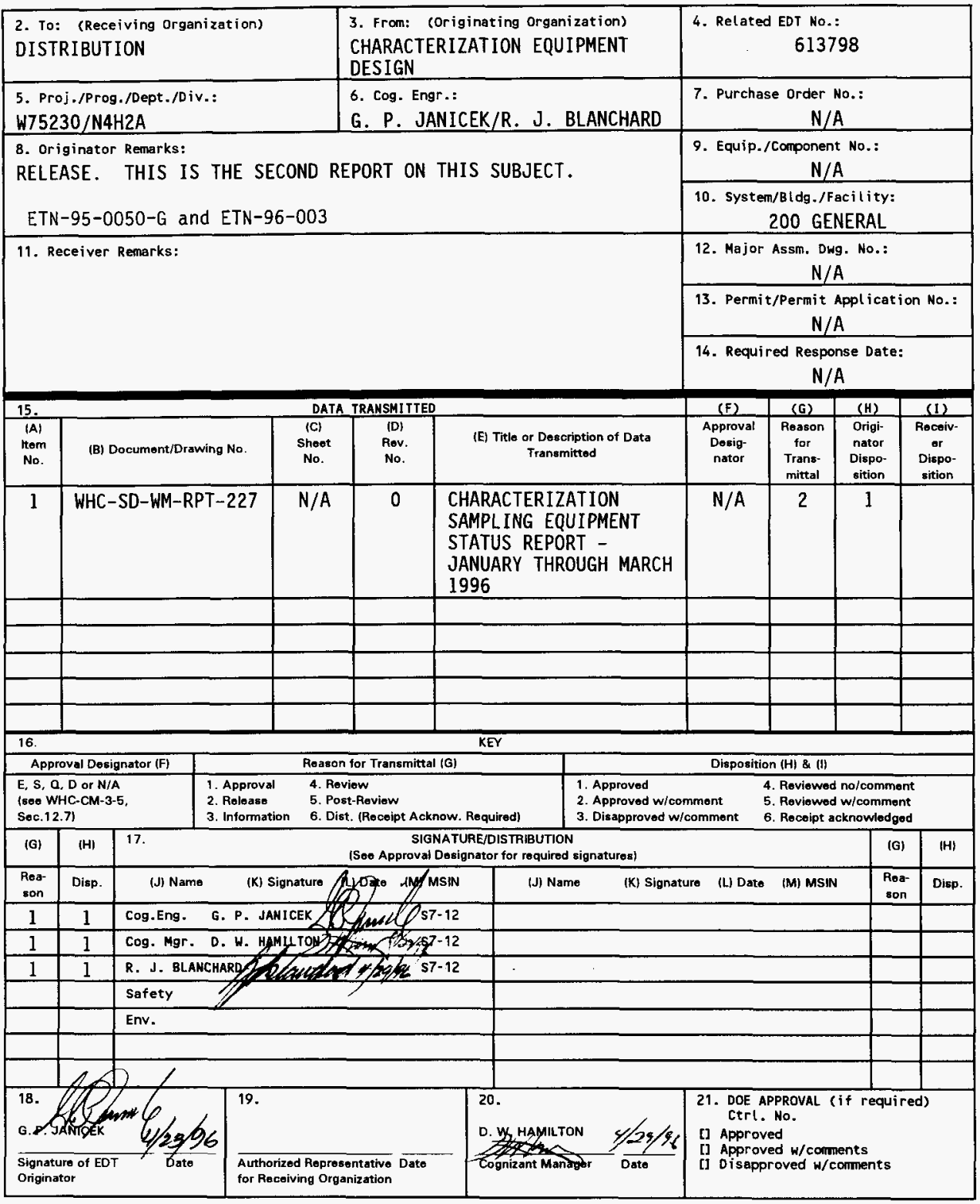




\title{
CHARACTERIZATION SAMPLING EQUIPMENT STATUS REPORT - JANUARY THROUGH MARCH 1996
}

\author{
G. P. Janicek and R. J. Blanchard
}

Westinghouse Hanford Company, Richland, WA 99352

U.S. Department of Energy Contract DE-AC06-87RL10930

\author{
EDT/ECN: 615401 \\ UC: $20>0$ \\ Org Code: 75230 \\ Charge Code: $\mathrm{N} 4 \mathrm{H} 3 \mathrm{~A}$ \\ B\&R Code: EW3/20074
}

Key Words: Characterization, Sampling Equipment, Samplers, Equipment Improvement, RMCS, Availability, Reliability, Core Sampling Trucks

Abstract: This report is the second status report on Characterization Sampling Equipment. It covers January through March 1996 activities. Subsequent reports are intended to be issued quarterly.

The degree of success in sample recovery and in the availability of equipment to take samples is reported on as are the measures being taken to track and improve recovery and availability. Planned activities are a) so presented.

TRADEMARK DISCLAIMER. Reference herein to any specific comercial product, process, or service by trade name, trademark, manufacturer, or otherwise, does not necessarily constitute or imply its endorsement, recommendation, or favoring by the United States Government or any agency thereof or its contractors or subcontractors.

Printed in the United States of America. To obtain copies of this document, contact: WHC/BCS Document Control Services, P.O. Box 1970, Mailstop H6-08, Richland WA 99352, Phone (509) 372-2420; Fax (509) 376-4989.
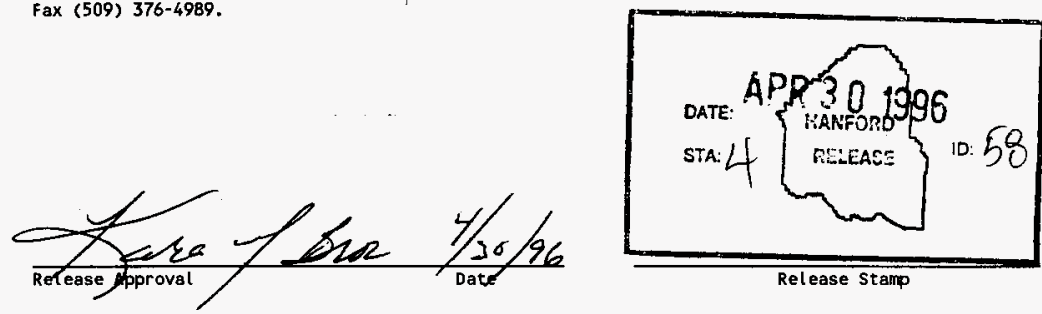

Approved for Public Release 


\title{
CHARACTERIZATION SAMPLING EQUIPMENT STATUS REPORT - JANUARY THROUGH MARCH 1996
}

\author{
WHC-SD-WM-RPT-227
}

Revision 0

Prepared By:

G. P. Janicek

R. J. Blanchard

WESTINGHOUSE HANFORD COMPANY

APRIL 1996 


\section{CHARACTERIZATION SAMPLING EQUIPMENT STATUS REPORT \\ JANUARY THROUGH MARCH 1996}

CONTENTS

EXECUTIVE SUMMARY ....................... 1

1.0 INTRODUCTION ........................... 1

2.0 HIGHLIGHTS - 2nd QUARTER FY96 .............. 1

2.1 IMPROVING SAMPLE RECOVERY . . . . . . . . . . . 2

2.1 .1 Key Parameters . . . . . . . . . . . . . . 2

2.1 .2 Data . . . . . . . . . . . . . 2

2.1.3 Sampling Improvements .............. 2

2.1 .4 Studies/Tests ............... . . 3

2.1 .5 Evaluations ............. . . . 6

2.2 EQUIPMENT AVAILABILITY/RELIABILITY IMPROVEMENTS . . . . . . 7

2.2.1 Equipment Development ............. 7

2.2.2 Equipment Modifications ............. 8

2.2.3 Management of Equipment Problems .......... 9

2.2.4 Equipment Problem Analysis/Corrective Actions . . . . . 11

2.2.5 Availability/Reliability Evaluations ........ 12

3.0 CURRENT ISSUES . . . . . . . . . . . . . . . . . . . . 12

4.0 PLANNED ACTIVITIES FOR THE NEXT REPORTING PERIOD . . . . . . . . 13

5.0 REFERENCES ........................... 13 APPENDIX A .............................. A01 
WHC-SD-WM-RPT-227, REV. 0

\section{CHARACTERIZATION SAMPLING EQUIPMENT STATUS REPORT JANUARY THROUGH MARCH 1996}

\section{EXECUTIVE SUMMARY}

Characterization Equipment Engineering continues to make significant steps towards the project goals of characterizing the Hanford High level waste tanks. With three Rotary-mode core sampling truck systems and one push-mode truck system operational during this reporting period the samples taken exceeded a 77 previous sampling rates. Two additional $X$-Ray imagers were deployed, to bring the total operational X-Ray systems to four. The scope of the imaging systems is being expanded to supply data on the quantity and size of gas bubbles/pockets captured in the "Retained Gas Sampler" to enhance to our understanding of the waste before it is extruded in the laboratory for analysis.

The majority of efforts planned in Engineering Task Plan, WHC-SD-WM-ETP159, "Improving Sampling Recovery, Engineering Task Plan" (Blanchard 1995) for this period were delayed in order to perform tests needed to support assumptions and provide data for the Safety Assessment (SA) of Rotary Mode Core Sampling in Flammable Gas Single Shell Tanks: Hanford Site, Richland, Washington, WHC-SD-WM-SAD-035, Revision 0 , being prepared by LOS Alamos National Laboratory.

Field testing of the new auger, noted in the 7 ast report, were completed with fairly good results. The auger, which incorporated the shallow pitch, small shaft features obtained high recovery, but on tank 241-TX-107 (riser 9A) a "tape" that was left in the tank wound around the auger shaft and the majority of the sample was lost untangling the recovered tape. The other tank auger sampled was 241-A-102 with excellent results.

\subsection{INTRODUCTION}

The purpose of this report is to status the activities and plans for improving sampling recovery and equipment availability/reliability. The reports are meant to be the library of facts for Characterization Equipment Engineering deliverables to the Characterization Project.

\subsection{HIGHLIGHTS - 2nd QUARTER FY96}

This report status the activities and plans accomplished by Characterization Equipment Engineering for the period from January 1, 1996 through March 31, 1996. 
WHC-SD-WM-RPT-227, REV. 0

\subsection{IMPROVING SAMPLE RECOVERY}

Planned activities to test and evaluate the attributes of the "TSAP Samplers" specified in Phase "B" Test Plan for New Core Samplers, WHC-SD-WMTP-409, Revision 0, were preempted by the need to support the Bit Temperature testing (Test report is in review), Ignitability Testing, WHC-SD-WM-TP-411, revisions 0 and 1 , and the Drill String Seal Pressure Test, WHC-SD-WM-TRP-251, Revision 0 . The test drill rig and test crew were needed to support the Ignitability Testing efforts conducted at the U.S. Bureau of Mines, Pittsburgh, $\mathrm{Pa}$. These testing efforts started in early January and are expected to be completed in late April or early May.

\subsubsection{Key Parameters}

During this period, three rotary-mode truck systems, and one push-mode truck system actively sampled waste at Hanford. Truck system \#l (Push Mode) obtained samples from Tanks 241-BX-104 (riser 7), 24l-BX-104 (riser 1) and 241-AW-101 (riser 24A). Truck system \#2 obtained samples from Tanks 241-S-102 (riser 11), 241-S-102 (riser 14), 241-S-101 (riser 4), 241-S-101 (riser 6) and 241-S-110 (riser 11). Truck system $\# 3$ obtained samples from Tanks 241-U-109 (riser 19), 241-U-109 (riser 7), 241-U-105 (riser 7) and 241-U-105 (riser 2). Truck system \#4 obtained samples from Tanks 241-U-107 (riser 9), 241-U-107 (riser 7), 241-U-107 (riser 2) and 241-U-105 (riser 2). During this reporting period 148 core segments had been taken by the four Truck systems. See section 2.1.5 Evaluations, for additional sampling performed in late 1995 , but not reported in the last quarterly report.

\subsubsection{Data}

Color core profiles of the samples taken during this reporting period are available from Characterization Equipment Engineering (CEE). In addition to the core profiles CEE is maintaining a book of laboratory generated pictures that capture the cores as extruded in the hot cell and the laboratory notes on the physical makeup of each core. These data bases are being used to determine recovery data, sampling profiles and comparisons of what the anticipated profile vs actual profile are, in addition to assisting the field cognizant engineers with decisions on upcoming sampling events.

\subsubsection{Sampling Improvements}

Testing of the samplers and bit developed by the Tank Sampling Assistance Panel (TSAP) planned during this period were preempted by the need to use the test drill rig and test engineers to support "Core Drilling Ignitability" testing at the U.S. Bureau of Mines, Pittsburgh, Pa., in support of the Safety Assessment (SA) for sampling in flammable gas watchlist tanks.

Auger sampling with the improved "shallow pitch fluted bit" was completed in two tanks, 241-TX-107 and 241-A-102. The results were very good with, but the recovery from 241-TX-107 was partially lost due to the fact that the auger, during sampling, captured a discarded manual tape (zip cord) in the auger flutes, and during the tape removal exercise, a large portion of the captured sample was lost (see Figure A01). The recovery in 241-A-102, was excellent, the first 26 flutes had sample medium (see Figure A02). As a comparison of the differences between the improved sampler configuration and the old design photo Figure $\mathrm{A03}$ (old configuration) is included. 
All four $X$-ray imaging systems were deployed in the field and available for use by mid January 1996. In addition, three of the four XRI systems have undergone a small modification to interior of the main $X$-ray cabinet to provide two sealed spaces between the waste contained in the sampler and the cabinets other interior spaces.

Some minor problems in operation of the X-ray imaging systems were identified during the severe cold weather in February 1996. Temperature limits were established in the system procurement document and the vendor literature and catalogues for components recommended that operation be limited to temperatures between 0 degrees Celsius (32 F) and 40 degrees Celsius (104 F). The equipment had been operated at colder temperatures before these 1 imits were realized. Observations made during the cold weather indicated that the $X-r a y$ equipment can perform as designed at temperatures as $10 \mathrm{w}$ as 10 degrees $F$, but not trouble free. At low temperatures moisture condenses on some components, and often the video image processors had to be re-booted several times before operating properly. Often, several video prints have to be generated with the thermal printer to obtain acceptable "noise free" images. The system vendor has agreed to provide Westinghouse a formal evaluation of the impacts and any added equipment needed for regular low temperature operation of the $X$-ray imaging systems. It is expected that the addition of some low wattage heat strips and some operating procedure changes providing for longer warm-up cycle time will permit trouble-free operation at below freezing winter temperatures.

\subsubsection{Studies/Tests}

The testing efforts required to support the safety assessment activities are being conducted per WHC-SD-WM-TP-411 revisions 0 and 1 , "Test Plan for Core Drilling Ignitability Testing" at the U.S. Bureau of Mines, Pittsburgh, $\mathrm{Pa}$.

The Rotary Mode Core Sampling Systems are currently on a hold due to concerns about the potential for igniting flammable gasses within the waste in the Hanford nuclear waste tanks. It has been speculated that an ignition of this flammable gas below the waste surface might occur while core drilling because of the rotational energy imparted to the waste via friction or sparking. In addition, the possibility of ignition because of the accidental dropping of certain rotary mode core sampling equipment (RMCSS) has been raised. Testing was initiated to address these concerns and provide sufficient level of confidence that ignition would not occur during normal Rotary Mode Core Sampling operations.

Areas of concern for this testing were broken down into two major categories:

1. Ignition caused by bit/waste or drill string/tank riser interaction; and

2. Ignition caused by accidental dropping of RMCSS equipment into or around the tank riser hole. 
WHC-SD-WM-RPT-227, REV. 0

\section{Current Status}

All tests involving the first major category above have been completed. The currently used Rotary bit (P/N 100IVD/5) had a minor modification made to it which involved replacing the carbon steel positioning pins with stainless steel pins. This change was made because ignition of the flammable gas occurred when using the bit with the carbon steel pins during testing. Once the change was made, no further ignitions occurred with the bit within the specified testing parameters. The revised bit is now referred to as Bogart Longyear P/N 100IVD/8.

A newer prototype rotary bit called the TSAP bit (developed by the Tank Sampling Assistance Panel) ( $P / N$ 9505-15) was also tested. This bit caused ignition in scenarios where the current standard bit did not. Although this bit was also modified by replacing the entire steel threaded shank section with stainless steel, drilling parameters still had to be altered so that lower energies were imparted to this bit in order to prevent an ignition. This bit is now referred to as Q.D. Design and Fabrication P/N 9505-15E.

As noted in the test plan, drilling involved controlling the following parameters; downward force, bit rotational speed, temperature of test chamber, species of flammable gasses used, and length of test (time). In addition, for tests involving the interaction between a piece of drill string and another piece of metal (to simulate a tank riser) a side load force was also controlled.

Table 1 below summarizes the tests completed. Note that three different flammable gas mixtures were used. These are identified as:

Mix 1 - A stoichiometric Hydrogen and Oxygen mixture

Mix 2 - A mixture of 30\% Hydrogen, $40 \%$ Oxygen and $30 \%$ Ammonia

Mix 3 - A mixture of 20\% Hydrogen, 20\% Ammonia and 60\% Nitrous 0xide

Note also that the test chamber temperature was held constant for each test at least $100^{\circ} \mathrm{C}$, that no purge gas of any kind was used for any test, and that each passing test was run at 1350 1bs and 65 RPM (except as noted). 
Table 1 - Drill Bit Tests Successfully Completed (no ignition)

\begin{tabular}{||l||c|c||}
\cline { 2 - 3 } \multicolumn{1}{c|}{} & \multicolumn{2}{c|}{ Number of Successful Tests } \\
\hline \hline \multicolumn{1}{c|}{ Test Scenario } & $\begin{array}{c}\text { Standard } \\
\text { Rotary Bit }\end{array}$ & TSAP Bit \\
\hline Drilling Into Rock Using Mix 1 & 5 & $\begin{array}{c}5 \text { @ } 860 \text { 1bs using } \\
\text { Hydrogen and Air } \\
\text { Stoichiometric mixture }\end{array}$ \\
\hline Drilling Into Rock Using Mix 2 & 3 & 3 \\
\hline Drilling Into Rock Using Mix 3 & 3 & 3 \\
\hline Drilling Into Stee1 Using Mix 1 & 5 & 5 \\
\hline Drilling Into Stee1 Using Mix 2 & 3 & 3 \\
\hline Drilling Into Steel Using Mix 3 & 3 & 4 \\
\hline $\begin{array}{l}\text { Drilling Into Rock Ten Times } \\
\text { With the same bit (3 minute test } \\
\text { then cool, then test....) }\end{array}$ & 1 0 1350 1bs & 1 0 1000 1bs \\
\hline
\end{tabular}

Table 2 below shows the tests completed which involved the rotating action of a drill string rubbing against a piece of steel. Note that for each test the resultant side load placed between the two metals was 200 lbs.

Table 2 - Drill String Side Load Tests Successfully Completed (no ignition)

\begin{tabular}{|c|c|c||}
\cline { 2 - 3 } \multicolumn{1}{c||}{} & \multicolumn{2}{c|}{ Number of Successful Tests } \\
\hline Test Scenario & With Pipe Lubricant & Without Pipe Lubricant \\
\hline $\begin{array}{c}\text { Smooth Carbon Stee1 } \\
\text { Drill String against } \\
4140 \text { Steel }\end{array}$ & 3 & 3 \\
\hline $\begin{array}{c}\text { Fluted Nickel Coated } \\
\text { Drill String against } \\
4140 \text { Steel }\end{array}$ & 3 & N/A \\
\hline $\begin{array}{c}\text { Fluted Drill String } \\
\text { with Nickel_Coating } \\
\text { Removed }\end{array}$ & N/A & 3 \\
\hline
\end{tabular}

The second major category which involves drop testing of various items is partially completed. The thirty drops of a piece of drill string from three feet have been completed. The current Remote Latching Unit (RLU) design is being modified to better absorb impact forces during a drop test since tests completed to date on the current RLU show an ignition in both a hydrogen and oxygen as well as a hydrogen and air stoichiometric gas mixture. 
Drill string seal pressure tests were performed in January and the results documented in WHC-SD-WM-TRP-251, Revision 0, "Test Report for Dri11 String Seal Pressure Test". These tests were ran to support the safety assessment being conducted by Los Alamos National Laboratory, and were to determine the volume rate loss in a typical drill string arrangement with varying conditions, i.e., with 0-rings, without 0-rings, with joint lubrication applied and without joint lubrication applied to the threads. Both Boart Longyear and Diamond Drill companies drill rods were used in the testing.

Test results show that drill rod leakage is lowered dramatically when thread lubrication is applied to the pipe threads and the joints tightened. This is true even when the 0-ring type drill rod (Bogart Longyear) has the 0ring missing or damaged. The Diamond Drill rod with no 0-ring groove has virtually no leakage with thread lubricant and the joint tightened.

\subsubsection{Evaluations}

Al1 core sampling with the rotary mode sample trucks during this period was done in push mode, no drill string rotation was used. Samples taken in November and December 1995 are included in this evaluation as this data was not included in the report for the previous period. Core profiles for each tank sampled are shown in figures A04 through A15. The rotary mode trucks obtained 195 samples during the period and the push mode truck obtained 28 samples.

The push mode sample truck (Truck System \#1) completed four cores, two cores on both 241-BX-112 and 241-BX-104, during November, December and January. Average recovery for the seven segments on $B X-112$ was an outstanding $91 \%$. Similarly, average recovery for the four segments on BX-104 was $93 \%$.

The push mode truck obtained samples from 241-AW-101 during the remainder of the period. Sampling is not yet complete, however five Retained Gas Samples have been successfully captured. Recovery is in excess of $90 \%$ for the first of two cores, each containing 22 samples.

The tanks which follow were all sampled with the rotary mode systems. Figure Al6 indicates the performance of the rotary systems (Truck Systems $\# 2,3 \& 4$ ) during this period.

Sampling on tank 241-BY-104 was successful in early November, averaging $67 \%$ for the 13 samples obtained from two cores.

Sampling on tank 241-B-203 was similarly successful in late November and early December. Average recovery for the 39 samples on B 203 was $65 \%$ including an average recovery for the third core of $79 \%$.

A second core was obtained on tank 241-BY-106 during late December. Success on this tank was good, in that recovery for the 12 samples taken averaged $64 \%$.

Three cores including 28 samples were taken on tank 241-U-109 between mid December and mid January. Performance was similar to other recently sampled tanks, averaging $66 \%$. A significant accomplishment was noted early in the sampling of $U-109$. On the third segment of the first core hard material was encountered. Use of the walkdown function and more frequent changing of 
samplers allowed successful penetration of the layering in the tank. Also of significance, all segments were obtained on this tank in just 9 sampling days even though severely cold weather hindered equipment reliability.

Sampling on tank 241-S-102 was very successful during January and March. Two cores were obtained, average recovery was $74 \%$. As with U-109, layers were also observed and successfully penetrated on S-102.

Tank 24l-U-107 proved difficult to sample with each of the three cores attempted during February and March. The drill bit encountered impenetrable material on each core. The first and third attempt penetrated only $25 \%$ of the waste depth, however the 2 nd attempt penetrated to $85 \%$ of the waste depth. Average recovery for all 20 samples on U-107 was $56 \%$.

Three cores were obtained on tank 241-U-105 during February and March, including 28 samples, averaging $45 \%$ recovery, the poorest performance of the quarter. Intrusion of nitrogen gas from the drill string into the sampler due to leaking samplers is suspected to be the cause of the reduced recovery.

Thirty-two samples from 3 cores were obtained from tank 241-S-101 during March. Average recovery was $41 \%$ for the first two cores, but recovery improved to $94 \%$ on the final core. This improvement resulted directly from the identification of nitrogen intrusion into the samplers. Of significance is the fact that the final core of $S-101$ was completed in a single day.

Tank 241-S-110 was the final location for sampling activity during the period. Only six samples were obtained from a single core. Recovery was excellent at $90 \%$, however a hard layer was encountered half way to the tank bottom which could not be penetrated with push mode. This tank was abandoned until drill bit rotation capability is restored.

\subsection{EQUIPMENT AVAILABILITY/RELIABILITY IMPROVEMENTS}

Equipment currently available to the Characterization Project for obtaining samples of wastes from underground tanks includes vapor samplers, grab samplers, auger samplers, and core samplers. The vapor, grab, and auger samplers are relatively simple devices and are easily deployed in the field with minimal attendant equipment. Core samplers require in-tank insertion by a complex, special-built drill rig truck with its own contingent of support equipment, which could include, for example, an exhauster, a diesel generator, electrical distribution and nitrogen supply trailers, a breathing air compressor, etc. A core sampling system (CSS) entails a much more complex operation and has a greater potential to adversely impact characterization Project objectives and schedules. For this reason a CSS is the primary focus of equipment availability/reliability improvements. The approach to improving equipment availability and reliability is documented in an Engineering Task Plan (Janicek 1995).

\subsubsection{Equipment Development}

Characterization Operations has had in its inventory, since July 11 , 1995, four CSSs: truck system \#1, capable only of push-mode core sampling, and truck systems \#2,\#3,\#4 capabie of both push- and rotary-mode core sampling, each using the universal core sampler. Truck system \#1 was acquired for use first, followed by truck system \#2 in order to add rotary-mode 
capability, and then in 1995 truck systems \#3 and \#4 were added simultaneously to improve overall sampling equipment availability. Each truck system comprises the drill-rig truck itself and all necessary supporting equipment. The individual truck systems are depicted in cartoon fashion in Figures A17A20. Truck system \#1 component equipment is configured differently than truck system \#2, and both \#1 and \#2 are configured differently than \#3 and \#4, reflecting the design evolution of the sampling trucks, themselves. For reasons of safety, reliability, and availability to be discussed in subsequent sections of this report there is has been an ongoing attempt to revise truck system \#1 and \#2 configurations to match that of $\# 3 / \# 4$. Consequently, the acquisition of one (1) additional generator (for truck system \#1) and two (2) additional electrical distribution trailers (for truck systems \#1 and \#2) was pursued during this reporting period. The generator had been delivered during the last reporting period, but was subsequently returned to the vendor for procurement corrections. The electrical distribution trailers are being fabricated onsite - fabrication was initiated during this reporting period. Both truck system component items are expected to be put into service in the near future.

During this reporting period a third and fourth $x$-ray imaging unit (XRI) were placed in operation, enabling each truck system to have an XRI. An XRI is used with a CSS to provided real-time imaging of the contents of core samplers after they are retrieved from in-tank, to ascertain percent recovery of waste material and to determine activation and position of sampler internal mechanisms.

Two different types of environmental structures were acquired and deployed to enable continuing operations and maintenance during inclement weather conditions, thus, improving overall equipment availability. One was a tent-type structure which could be erected over each core sampling truck while it was deployed in a tank farm, over a tank riser, and engaged in sampling operations. The other was a rigid walled dome similar to those often seen along highways and used by highway departments for the storage of materials. The dome serves as a place to perform planned maintenance and equipment modifications outside of the tank farm and in close proximity to a full complement of operations, maintenance crafts, and engineering personnel.

Two (2) $15 \mathrm{Kw}$ generators were acquired to support planned maintenance and equipment modification outages being performed in the newly acquired dome structure.

\subsubsection{Equipment Modifications}

As reported previously, the acquisition of truck systems \#3 and \#4 was accomplished using design drawings from truck system \#2 and making minimal changes thereto, $\cdots$ so as to-expedite the acquisition. This resulted in a 1 ist being generated of known modifications to sampling trucks \#2, \#3, and \#4 that would improve their operational reliability, but which would have to wait to be implemented during future maintenance outages. Operational experience has seen a growth in the number of items on this list. Figure A2l depicts a listing of thirteen (13) of the more visible modifications planned and their status as regards each of the four trucks. 
In addition to reliability modifications, modifications to improve safety, operability, maintainability, availability (as a result of operational and field problem experience), and those required to satisfy the safety assessment of rotary-mode operation in flammable gas watchlist tanks have been identified and listed for each truck. Figures A22-A24 depicts such a 1ist for truck system \#3. A similar listing has or is being generated for each truck on a truck system basis. Truck system \#3 was chosen to be shown here since it was the only truck to experience a planned maintenance and modification outage during the reporting period. The flammable gas modifications have not yet been implemented and are planned. These modifications primarily rely on elimination of ignition sources in the in-tank and out-of-tank sampling and support equipment exposed to flammable gas pathways. It should be noted on the list depicted that many of the implemented or planned modifications often result in required modifications/revisions to maintenance and operating procedures and also spare parts.

A weekly meeting involving design engineering, field engineering, operations, and maintenance was estabilished to review and status the required modifications to each truck system. Normally, the truck system currently in a planned outage and/or the next truck system scheduled for an outage are concentrated on during this meeting. As noted above, truck system \#3 was the only one to undergo an outage during this reporting period. Truck system \#4 is next scheduled. If at all possible, \#3 and \#4 are scheduled to follow each other in modification outages since the two systems are twins, built to the same set of drawings, and its desirable to keep them together in design configuration.

Specific improvements which were reported previously as planned to be done during this reporting period and which were accomplished include sampler pintle release mechanism and remote latching unit mechanism (RLU) design changes. The previous pintle release mechanism employed a shear wire design which was meant to cause the sampler pintle to be withdrawn from the sampler in the drill string within a known pulling force range. In some cases the shearing occurred prematurely resulting in no sample being obtained and in other cases it would exceed both the range and limit of the grapple hoist system. This shear wire design has been replaced with a spring design. The RLU, used to set and retrieve the samplers in the drill string is electric motor driven and relies on overcurrent protection to avoid shearing of its drive shaft. This has not been reliable protection and has resulted in RLU failures. The RLU has been redesigned to operate totally mechanically using gravity forces and is currently undergoing testing. It is intended to be deployed during the next reporting period.

\subsubsection{Management of Equipment Problems}

As reported previousty, logbooks are kept by Characterization 0perations and Characterization Field Engineering for each truck system. These are used to document equipment problems experienced in the field and other fieldrelated activities. A sampling problem database created by Characterization Equipment Design is used to collect, sort, analyze, assign responsibility, and document closure for problems related to sampling operations and equipment, as gleaned from the logbook systems identified. The database is available to everyone on the Characterization Project via a computer drive on the local area network. It can be found at network share, IIWHC128\ACTLOG, commonly referred to as " $K$ " drive. During the reporting period an additional 364 
"problem" entries were made to this database. Not all of these are specific sampling equipment problems demanding engineering attention. Many are smaller "problems" requiring a maintenance response and many are of a personnel or material resource nature. A few involve the language or interpretation of operating procedures. A weekly meeting between representatives of design engineering, field engineering, operations, and maintenance was established during this reporting period to review the weekly input to the "problem" database and establish problem solution responsibility. Those problems designated as belonging to design engineering are further reviewed within design engineering and are assigned to an individual engineer to resolve. If it's determined that the solution requires an equipment design modification, that is so noted and the required modification is added to the truck system modification database (see item 2.2.2 above).

The problems which are cause for high sampling equipment unavailability are given the highest priority for resolution by design engineering. Figure A25 depicts the percentage distribution of causes for sampling equipment unavailability during the first half of FY96. Seven specific and one miscellaneous grouping from all other causes are depicted. The number one cause of sampling equipment downtime is associated with the grapple hoist system and in particular the tendency of the hoist cable to jump off of its spooling drum and become entangled on its drive system inside its "confinement" box. Figure A26 lists the equipment modifications planned or implemented during this period to address each of these high profile equipment unavailability causes.

It is well recognized that all equipment field problems are not the result of faulty design. Sometimes the fault can be traced to faulty procedures. Often problems are the result of human error or lack of training or understanding of how the equipment is intended to function. In an effort to improve equipment availability (or incidence of unavailability) as regards operator understanding Characterization Equipment Design initiated a

supplemental "training" program for operations and maintenance personnel. Once a week, for four weeks, each of the four shifts are trained in a specific area of sampling equipment operation. During this reporting period three such sessions were conducted which included the topic areas of:

- Problem/Trouble Log system - reporting and resolution of sampling equipment problems.

- Chapter 6 of the Safety Assessment for rotary-mode core drilling in flammable gas Watch List tanks - design feature changes and administrative controls being implemented.

- Samplers - design/development history, current design, design evolution changes.

During this reporting period a problem area surfaced which was not specifically of a faulty design nature (although, design changes are being considered as a portion of the problem solution) but more of a lack of procedural and/or an administrative control as a result of design ignorance. The problem is a result of mixing and interchanging truck system component equipment in the field in response to certain components being or becoming inoperative and in order to not have to cease sampling operations. The result has been that incompatibilities have occurred due to interchanged component equipment. In one instance a substituted generator caused a pump motor and its subsequent replacement to burn up. In another instance substitution 
caused the casing of a piece of equipment to be energized with electrical line voltage instead of being grounded. The immediate response has been to place administrative controls on substitution/interchanging of truck system component equipment, establish an interchangeability matrix, and specify the voltages and wiring to be employed on each type of electrical plug and socket connection existing on field equipment (even though none of the problems involved an NEC violation). The long term solution planned will create truck system design configurations (as alluded to in section 2.2.1 above) and modify existing and new pieces of truck system component equipment to enhance interchangeability.

\subsubsection{Equipment Problem Analysis/Corrective Actions}

As reported previously, the immediate response to an equipment problem in the field that shuts down operations is normally one of repair-in-place or replace with a spare component to facilitate resumption of operations whenever possible. After the fact, the problem or failure is analyzed as to cause and whether corrective actions in the form of equipment modifications are warranted. In some instances the root cause of the problem or failure is not readily apparent and an analysis (formalized during the previous reporting period) is required. During this reporting period equipment problems/failures were of a nature to readily ascertain their causes through inspection, discussion, or simple test and no formal analyses were performed. Figure Al0 (discussed in section 2.2.3 which lists equipment modifications planned or implemented) mentions some of these causes in response to the more prevalent problems experienced during this period. For example, the "quadralatch aluminum nut failure" problem had to do with the quadralatch finger assembly, by which a sampler is retrieved from the drill string, becoming separated from the sample tube itself, resulting in the entire drill string having to be disassembled in order to retrieve the sample tube. Inspection revealed that the aluminum nut which held the two portions of the sampler together had essentially dissolved/softened thus allowing them to separate. Other aluminum portions of the sampler mechanism were similarly affected. A simple chemical test revealed that tank waste materials will indeed dissolve/soften the aluminum being used. A sampler is used only once and then discarded once the sample is extracted in the lab. Also, the sampler normally resides in the drill string for only and hour, more or less, during sampling operations and through design and procedure is not intended to contact tank waste external to the sample tube. During this period a number of samplers had to be left in their respective drill strings for extended periods of time. In response, all sampler nuts are being changed to stainless steel.

In one instance during this reporting period a formal investigation into a drill string "sparking" incident (of concern on flammable gas watchlist tanks) was conducted by Characterization Equipment Engineering. As two sections of drill-string rod-(carbon steel material) were being unthreaded they sprung apart and caused a large, noticeable spark to occur. Electrical testing ruled out an electrical problem. Other testing revealed that the striking together of drill rod pieces would produce a spark, but not of such character as was observed in the field. However, with the addition of an anti-seize joint compound to the rod threads (of a type being used at the time) sparking was indeed enhanced. 
The compound contained powdered aluminum and a thermite flash was considered to be what was observed. Response to this incident was to better control the alignment of the drill string during operations and to use only threaded joint compounds approved for use with gas pipelines.

During this period core sampling was limited to push-mode only because of flammable gas issues with rotary-mode sampling. In an effort to permit higher downforces when pushing into tank waste (in order to enhance the number of tanks that can be sampled in push-mode only) and also to provide additional protection from drill string buckling (a drill string failure due to buckling was experienced during the previous reporting period) tank riser sleeves were designed, fabricated, and deployed. These sleeves act as strongbacks for the drill string which is inserted through them. The sleeves were fabricated using schedule 80 steel pipe. In conjunction with acquisition of these sleeves an analysis on their use was commissioned and initiated. Results of this analysis are being used in field operations when required. Formal issuance of this analysis report is expected during the next reporting period.

\subsubsection{Availability/Reliability Evaluations}

As reported previously, the working definitions for availability and reliability of sampling equipment have been established in Janicek (1995). As defined, the availability of CSSs is tracked daily. Concurrence in equipment status is established between Characterization Equipment Engineering and Characterization Operations. Equipment availability for the reporting period, as shown in Figure A27, was $72 \%$. Contrast this with $57 \%$ for the first quarter of FY96, which, as also reported previously, was primarily due to a gas flammability issue with certain tanks which surfaced in November 1995 and prevented use of $\mathrm{planned}$ rotary-mode core sampling. During the current reporting period the schedule of tanks to be sampled was revised to accommodate push mode sampling since rotary-mode gas flammability issues were still undergoing resolution. This allowed sampling operations to continue during this reporting period in spite of the fact that the number of tanks that can be sampled in push-mode is fast becoming limited. Rotary-mode capability will soon be needed. The FY96 goal of attaining an average $65 \%$ availability is within close reach (as shown) but was not achieved during this quarter. (NOTE: 3 shifts per day are available for using the truck systems. A11 truck systems \#1, \#2, \#3, and \#4 were on-line for all of the reporting period, except that, truck system \#3 was in a three week planned maintenance and truck modification outage in March which is charged as unavailable time).

\subsection{CURRENT ISSUES}

As reported previously, flammable-gas Watch List Tank controls were added to more tanks. - This cont inues-to impact the rotary-mode sampling schedule, because many of the tanks most desirable to be rotary-core sampled for characterization cannot now be sampled. During this period many activities continued in an attempt to qualify the equipment and satisfy the safety assessment concerns so that rotary-mode core sampling can be resumed. A 1 ist of modifications under way or planned to address this issue is shown in Figures A06-A08 as type FGAS modifications. 


\subsection{PLANNED ACTIVITIES FOR THE NEXT REPORTING PERIOD - 2ND QUARTER FISCAL YEAR 1996}

Testing at the U.S. Bureau of Mines will be completed when the sixty foot drop tests of the sampler onto the rotary and push mode bits as well as the sixty foot Remote Latch Unit (RLU), with modified weights, drop test is completed.

Equipment availability/reliability improvements during this reporting period have mainly focused on hardware. This emphasis will continue for the next reporting period. These are intended to be implemented as scheduled maintenance outages allow. In addition it is planned that truck systems will be defined and be placed under system design configuration control.

\subsection{REFERENCES}

Blanchard, R.J., 1995, "Improving Sample Recovery, Engineering Task Plan," WHC-SD-WM-ETP-159, REV. 1, Westinghouse Hanford Company, Richland, Washington.

Janicek, G.P., 1995, "Sampling Equipment Availability/Reliability Improvement, Engineering Task Plan," WHC-SD-WM-ETP-171, REV. 0, Westinghouse Hanford Company, Richland, Washington.

McCormick, J.F., 1995, "Phase 'B' Test Plan for New Core Samplers," WHC-SD-WMTP-409, REV. 0, Westinghouse Hanford Company, Richland, Washington.

Witwer, K.S., 1996, "Test Plan for Core Drilling Ignitability Testing," WHCSD-WM-TP-411, REV. 1, Westinghouse Hanford Company, Richland, Washington.

McCormick, J.F., 1996, "Drill String Seal Pressure Test," WHC-SD-WM-TRP-251, REV. O, Westinghouse Hanford Company, Richland, Washington. 
WHC-SD-WM-RPT-227, REV. 0

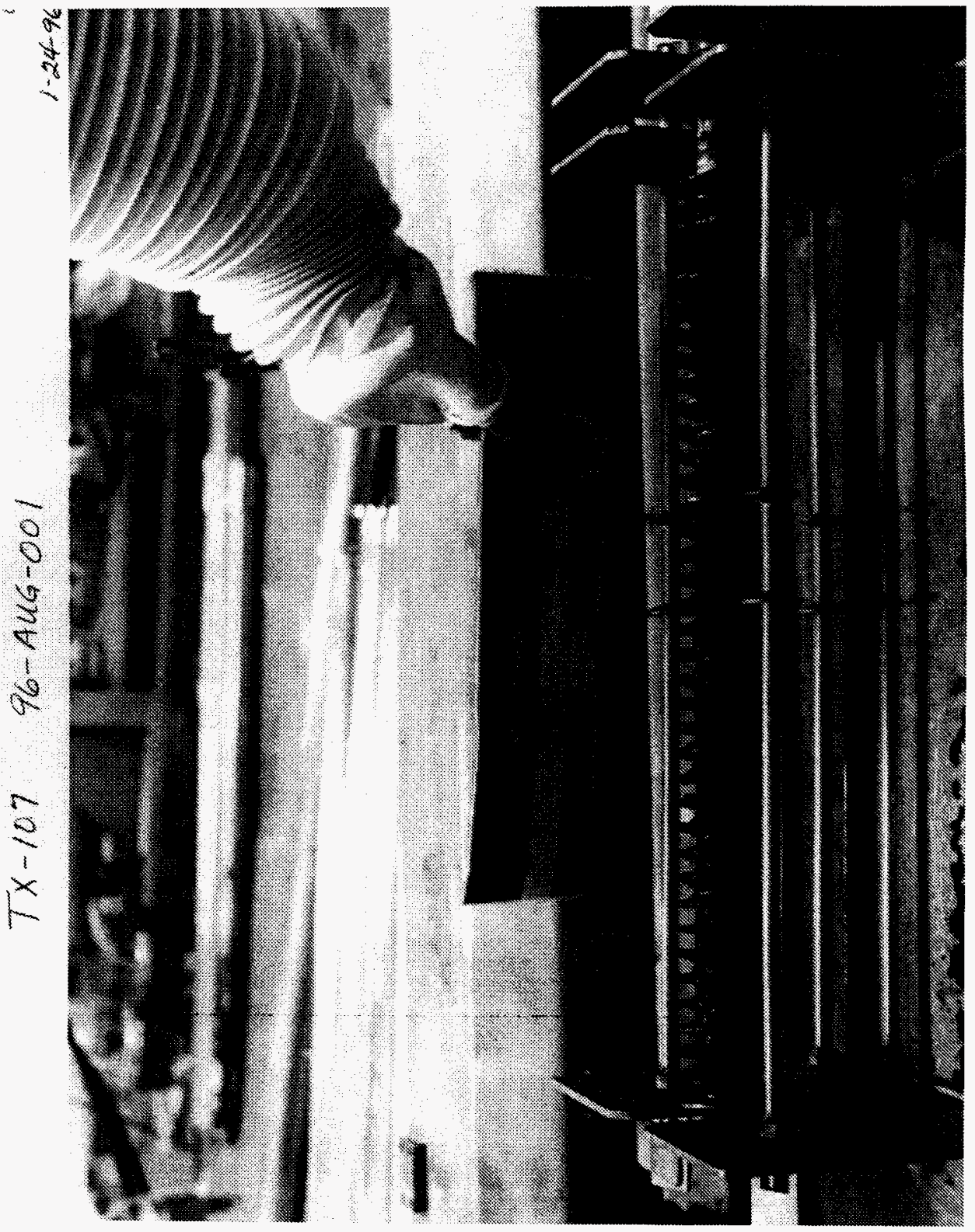


WHC-SD-WM-RPT-227, REV. 0

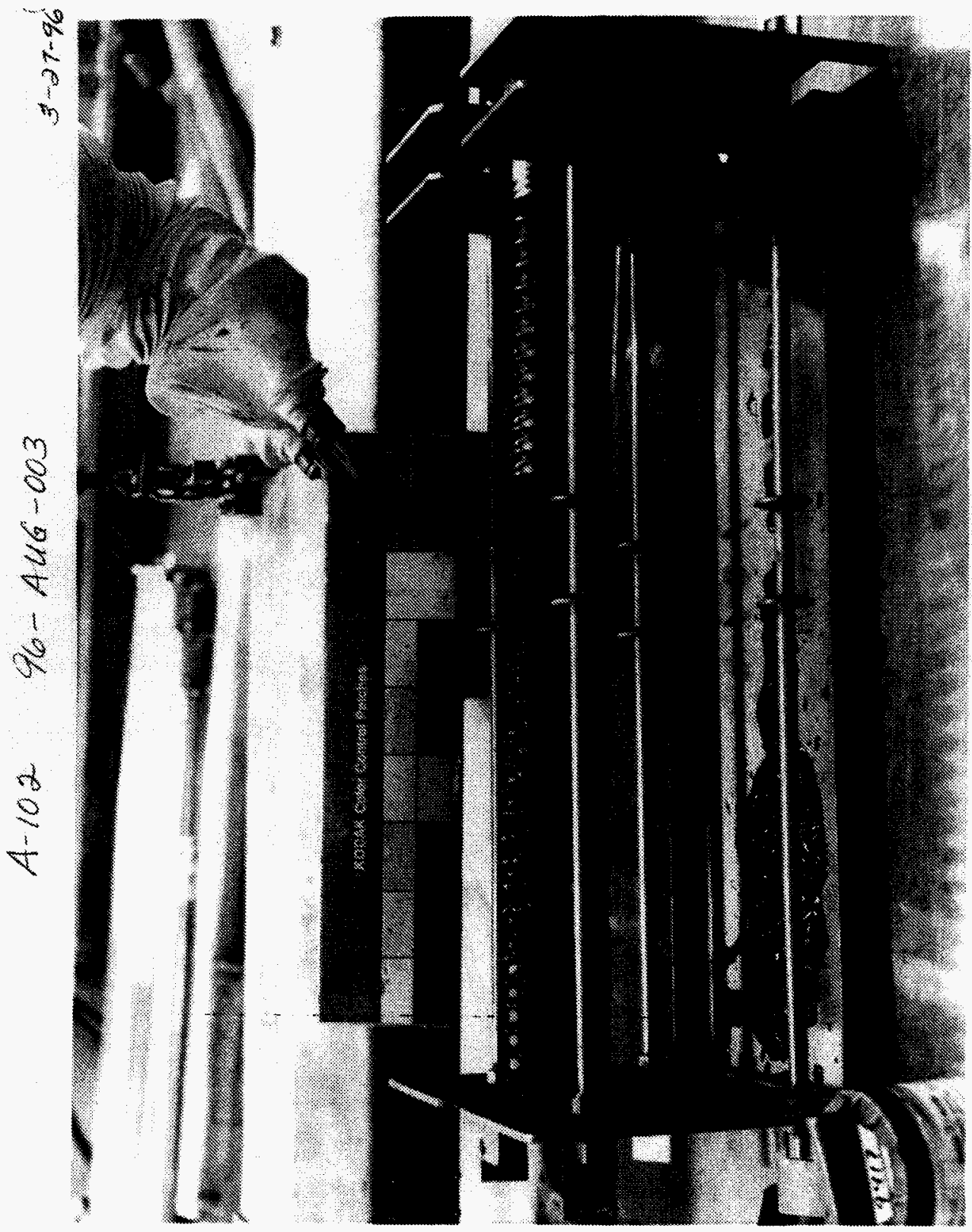




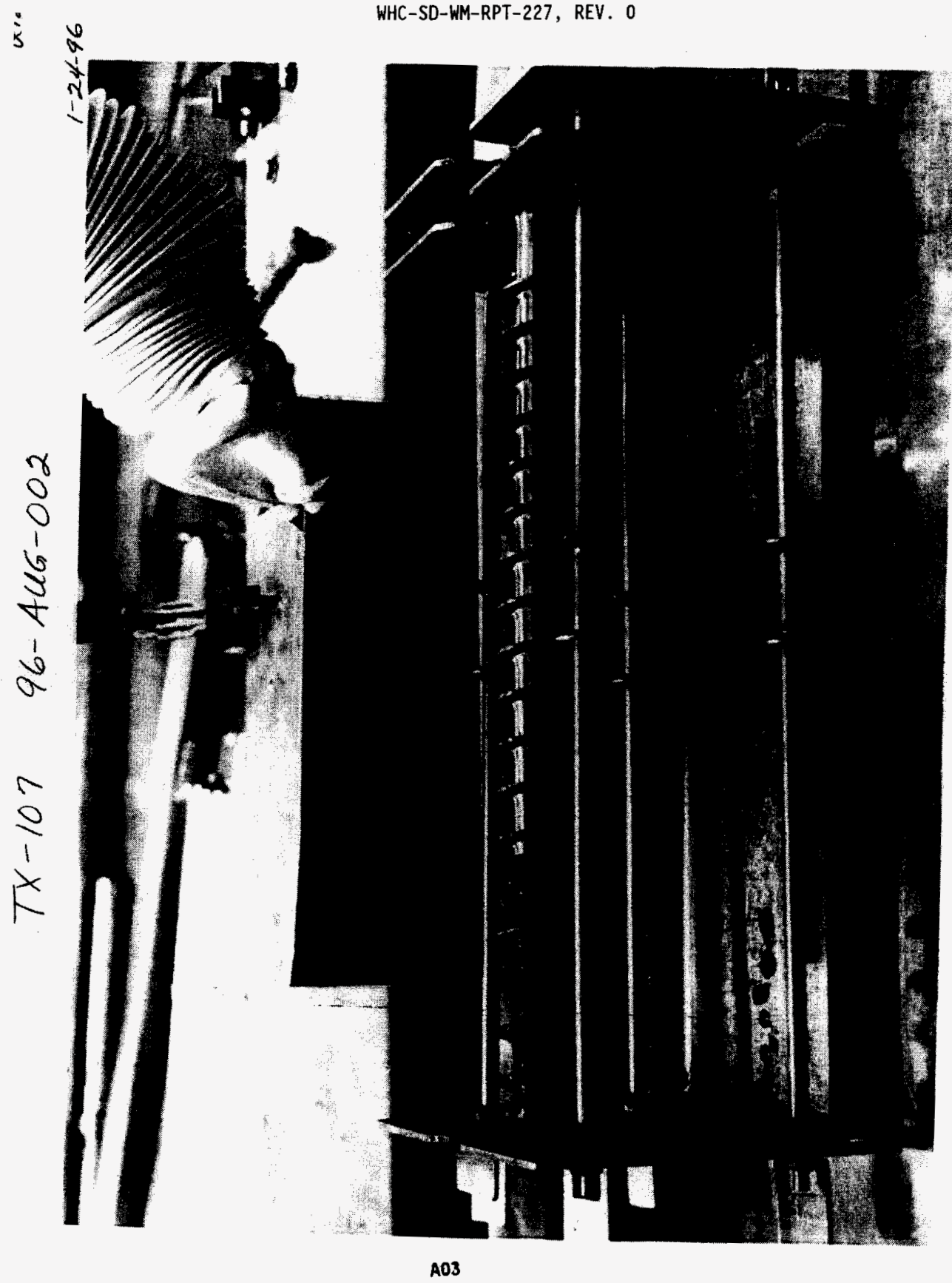




\section{AW-101 PMCS CORE PROFILE}

FHLE: AW 101 CRD

DATE: $04 / 28 / 96$

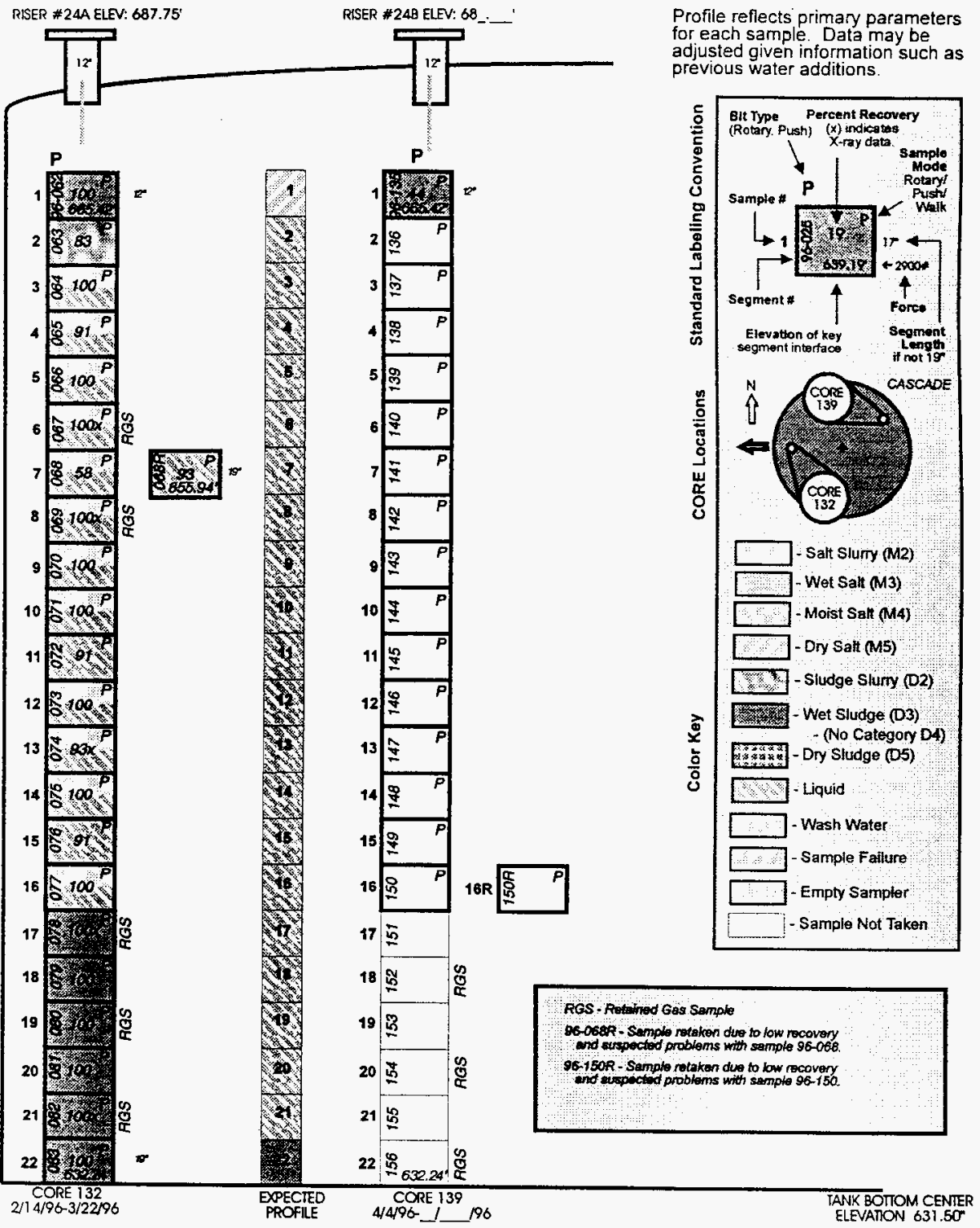




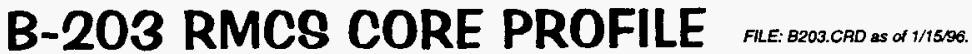

Profiles below indicate primary constituent in sampler and are intended to reflect tank waste conditions. In some instances, extrusion information may be adjusted knowing other key information such as previous water additions. RISER \#2 ELEV: 651.94"

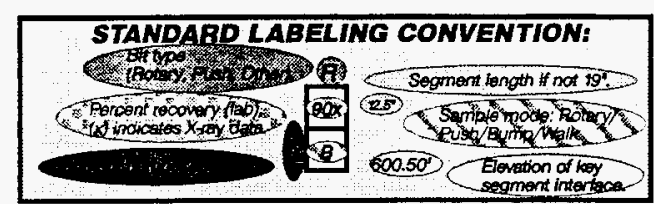

RISER \#7 ELEV: 651.96

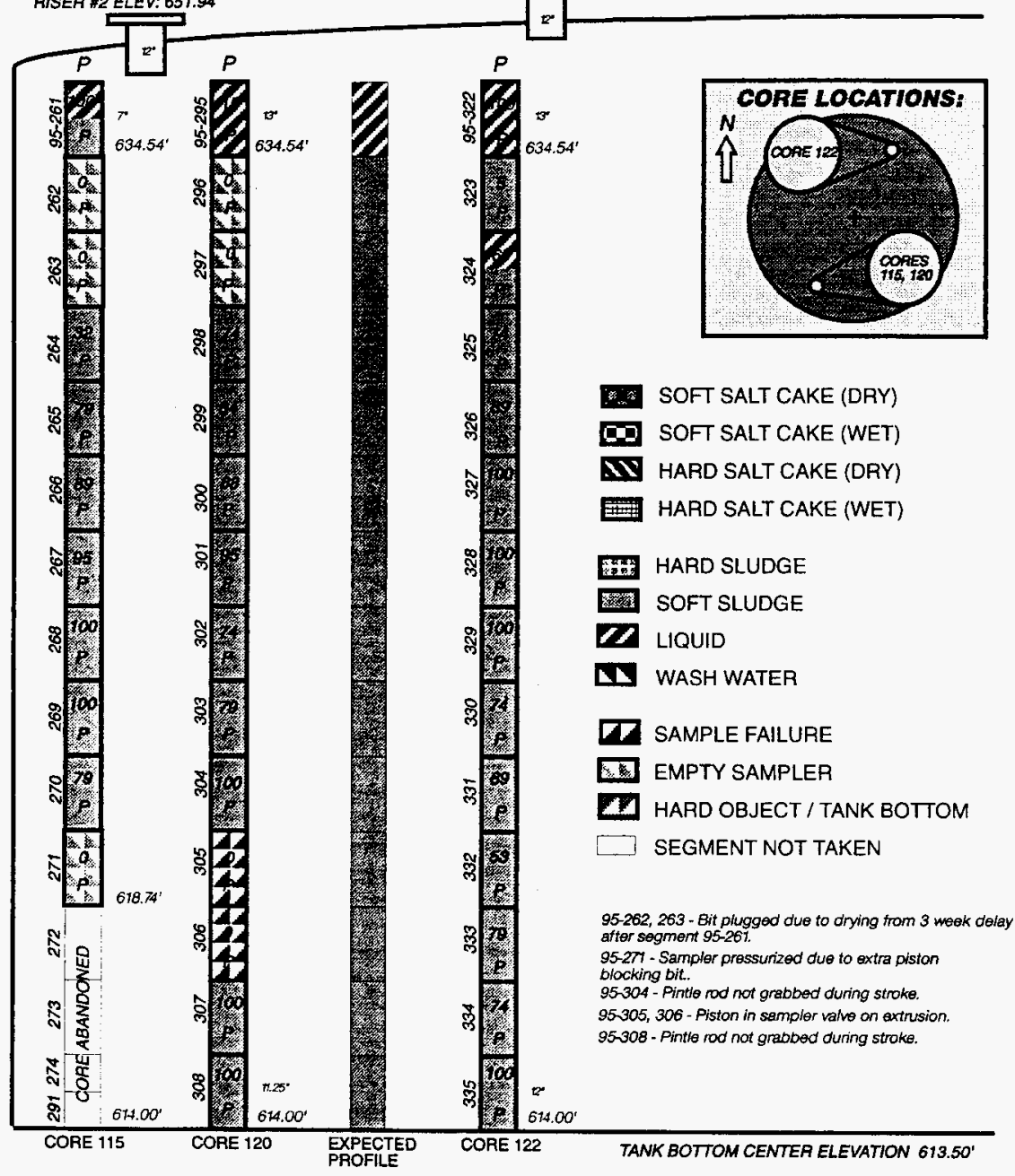




\section{BX-104 PMCS CORE PROFILE}

FILE: EX104.CRD as of 02/07/96.

SOFT SALT CAKE (DRY)

Hing

HARD SLUDGE

SAMPLE FAILURE

[D] SOFT SALT CAKE (WET)

SOFT SLUDGE

EMPTY SAMPLER

NV HARD SALT CAKE (DRY)

CA LIQUID

24 HARD OBJECT / TANK BOTTOM

HARD SALT CAKE (WET)

WASH WATER

\section{SEGMENT NOT TAKEN}

Profiles below indicate primary constituent in sampler and are intended to reflect tank waste conditions.

In some instances, extrusion information may be adjusted knowing other key information such as previous water additions.
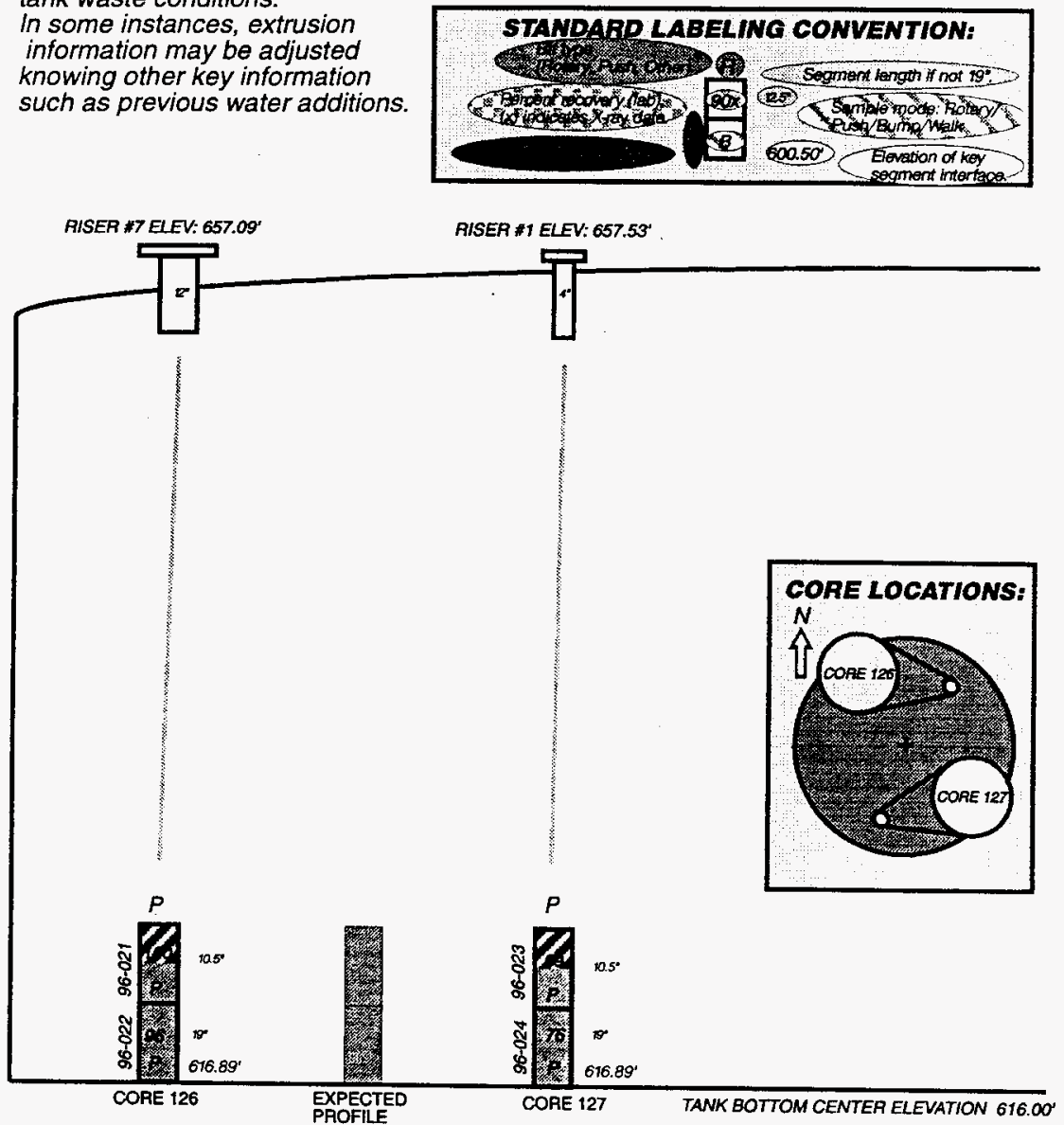
WHC-SD-WM-RPT-227, REV, 0

\section{BX-112 PMCS CORE PROFILE}

FILE: BX112CRD as or 01/30196.
SOFT SALT CAKE (DRY)
HARD SLUDGE
SAMPLE FAILURE
DO SOFT SALT CAKE (WET)
SOFT SLUDGE
NV HARD SALT CAKE (DRY)
Ca LuUID
意
EMPTY SAMPLER
HARD SALT CAKE (WET) M WASH WATER
24 HARD OBJECT / TANK BOTTOM
SEGMENT NOT TAKEN

Profiles below indicate primary constituent in sampler and are intended to reflect tank waste conditions.

In some instances, extrusion information may be adjusted knowing other key information such as previous water additions.
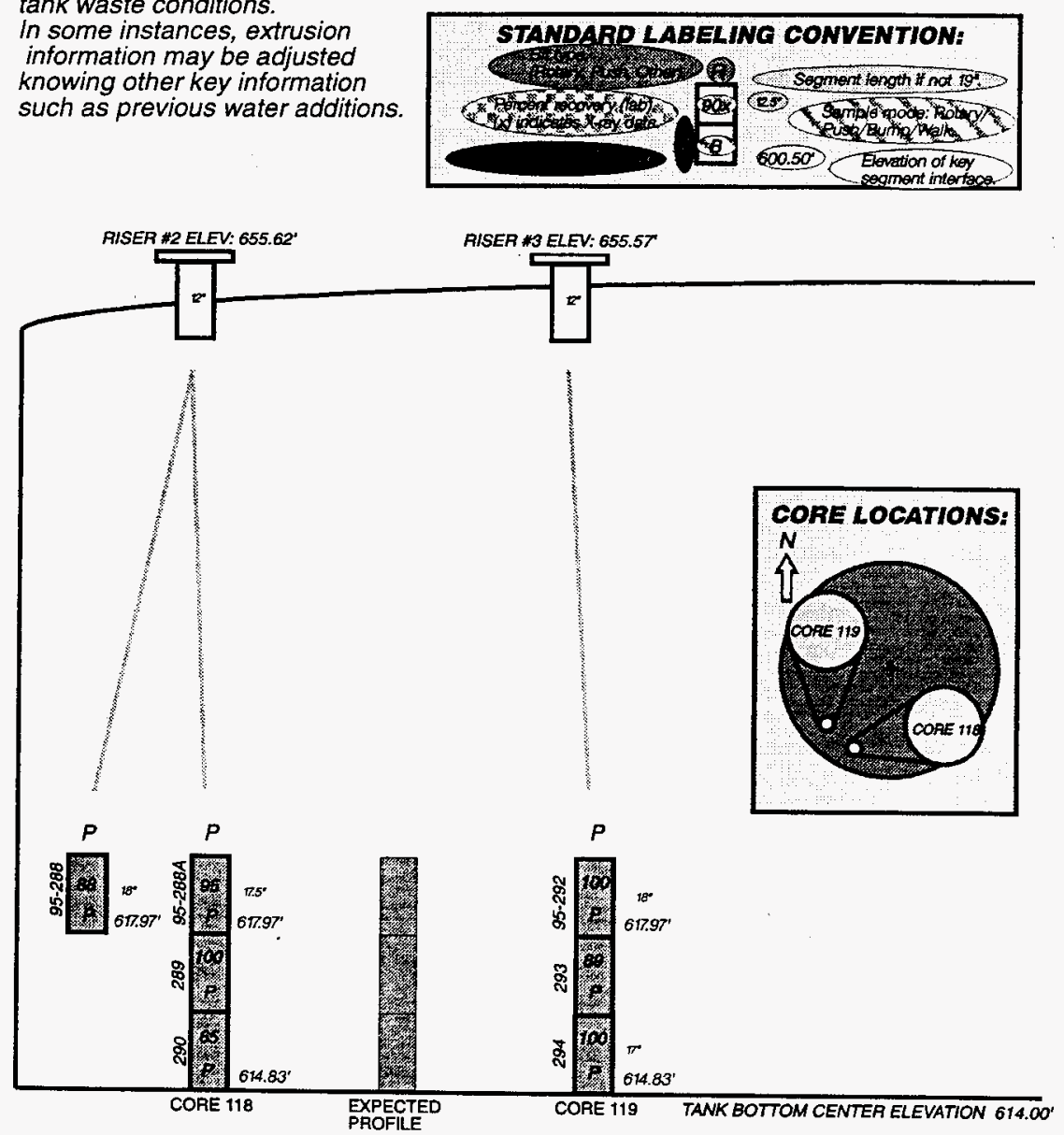


\section{WHC-SD-WM-RPT-227, REV. 0 \\ BY-104 RMCS CORE PROFILE \\ FILE: BY104.CRD as of 12/15/95}

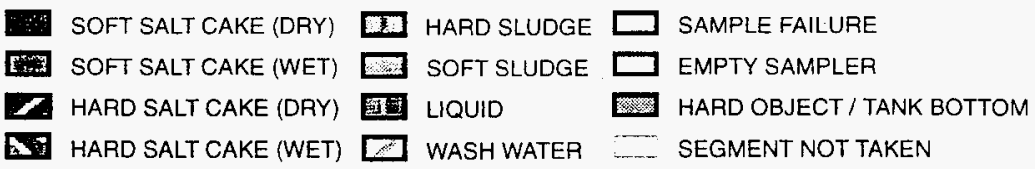

Profiles below indicate primary constituent in sampler and are intended to reflect tank waste conditions.

in some instances, extrusion information may be adjusted knowing other key information such as previous water additions.
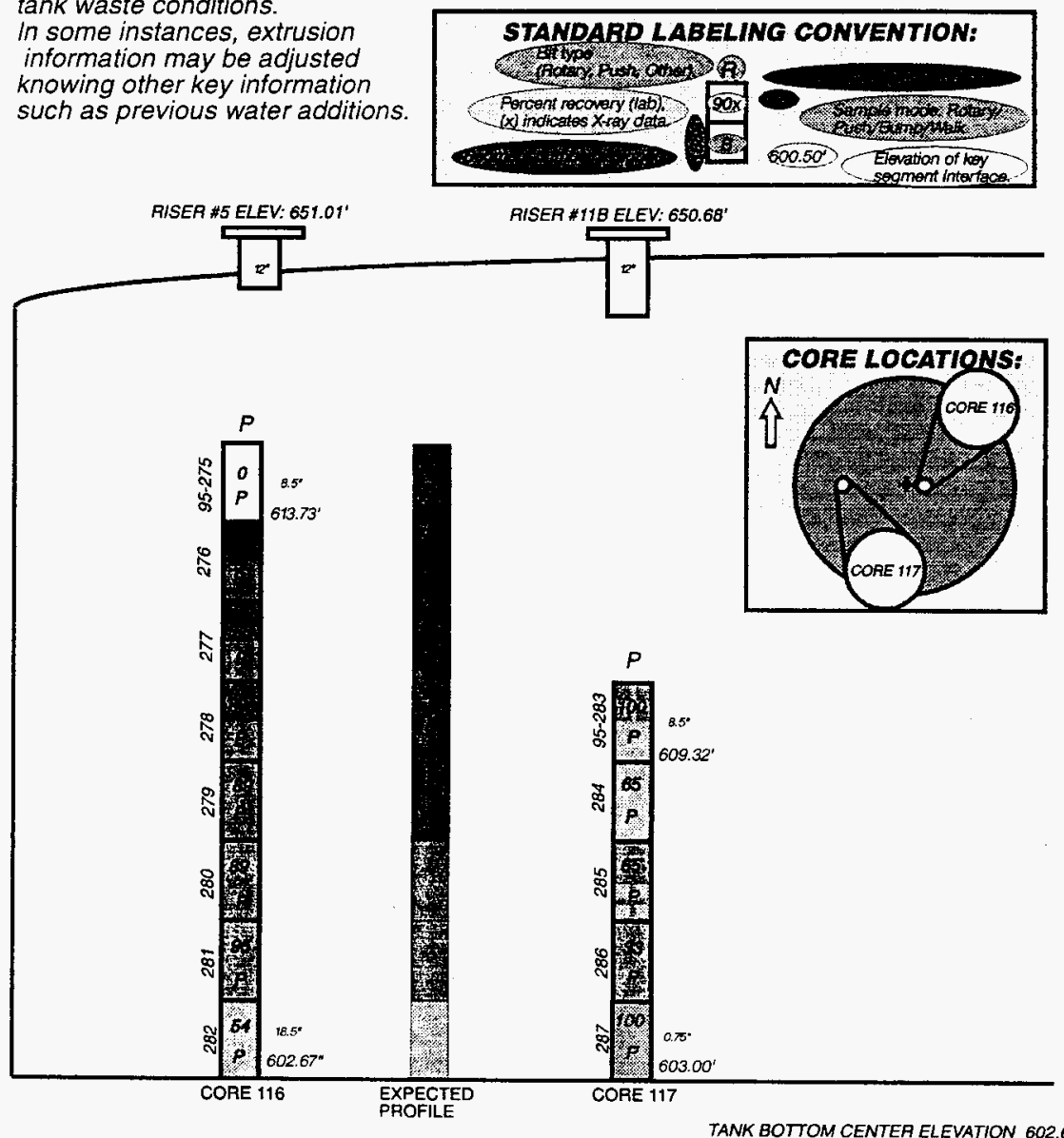


\section{BY-106 RMCS CORE PROFILE}

FLE: BY106.CAD as of 1222/95.

Profiles below indicate primary constituent in sampler and are intended to reflect tank waste conditions. In some instances, extrusion information may be adjusted knowing other key information such as previous water additions.

RISER \#1OB ELEV: 648.33

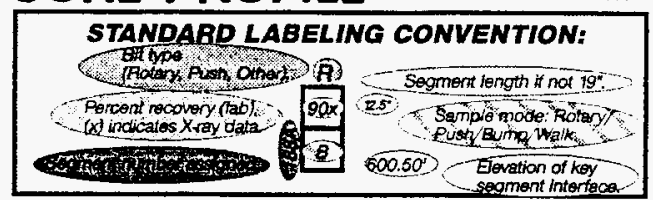

RISER *5 ELEV: 649.12'

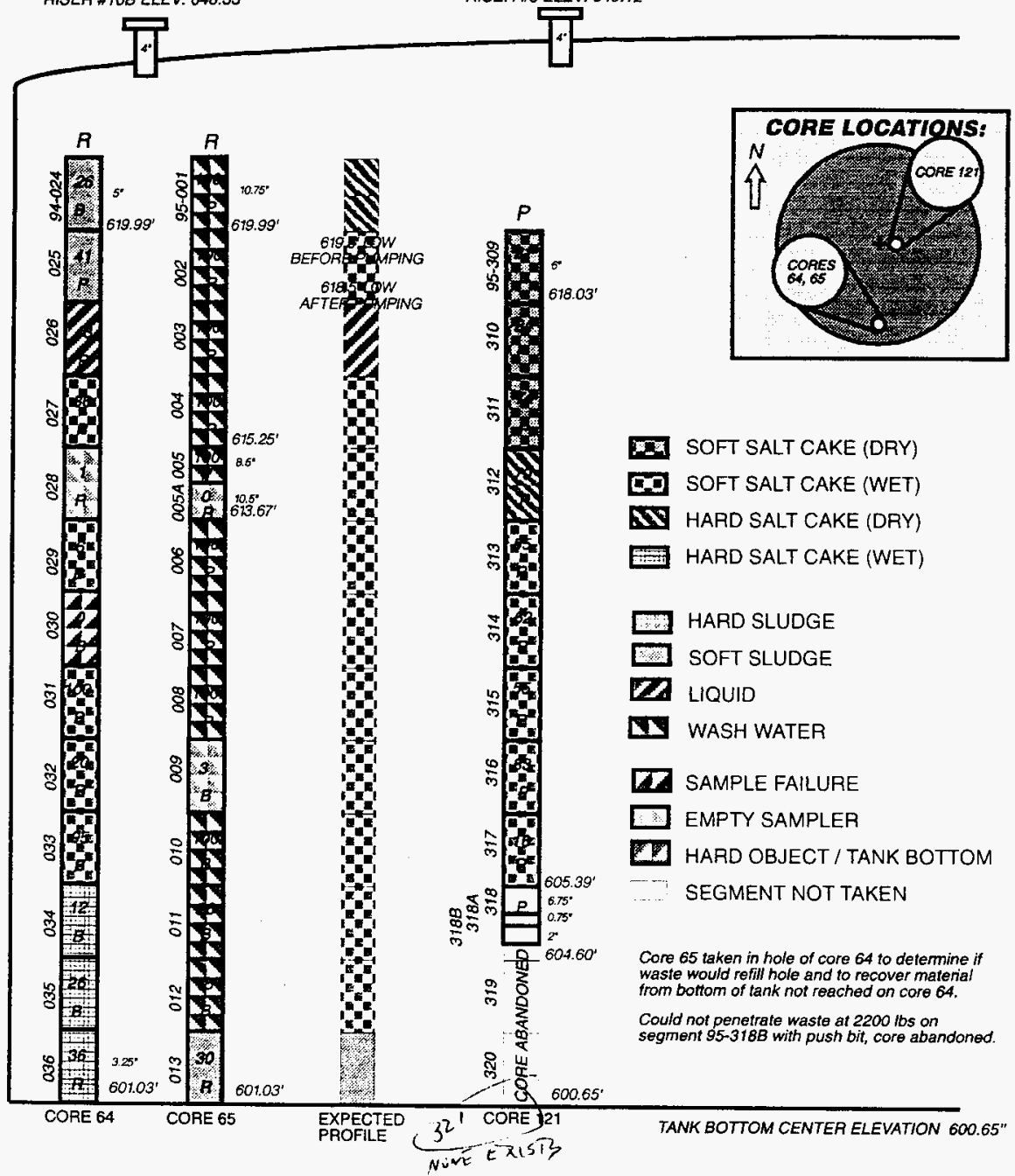




\section{8-101 RMC8 CORE PROFILE}

FILE: S101.CRD DATE: 04/28/96

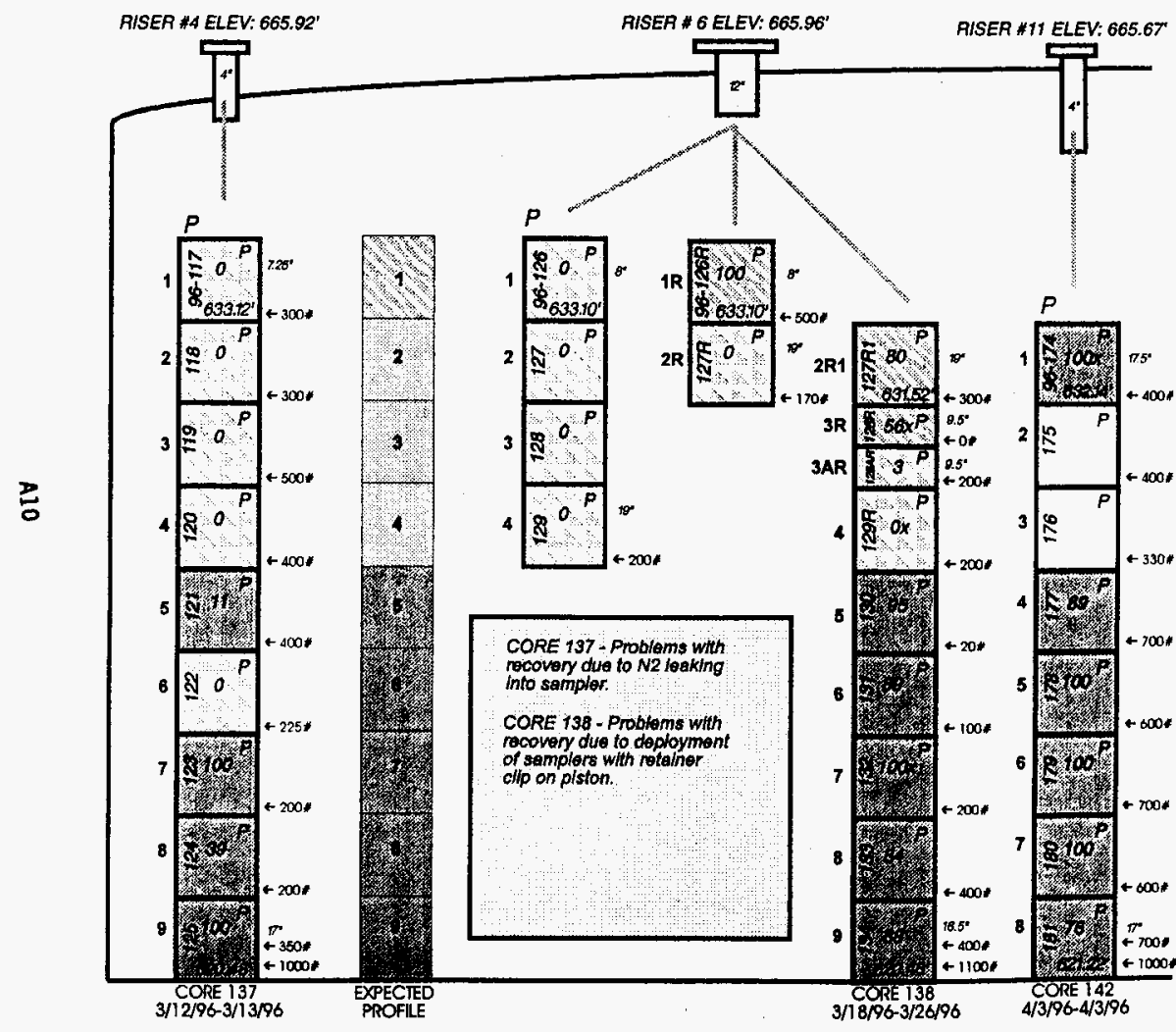

Profile reflects primary parameters for each sample. bata may be adjusted. given information such as previous water additions.

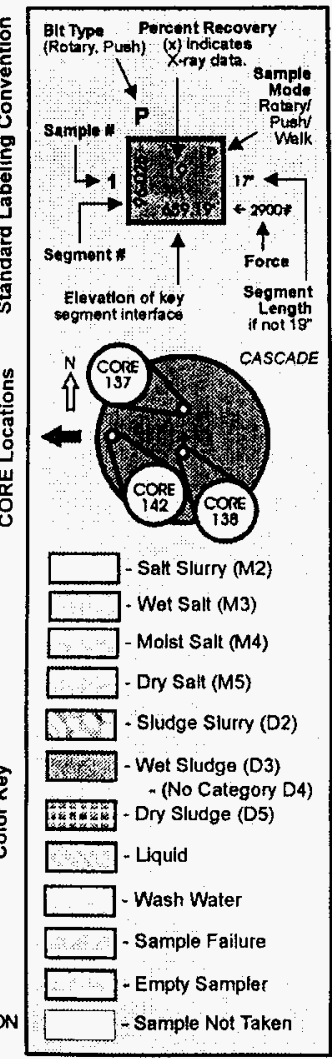




\section{S-102 RMCS CORE PROFILE}

FILE: STO2.CRD as of O404196

Profiles below indicate primary constituent in sampler and are intended to reflect tank waste conditions. In some instances, extrusion information may be adjusted knowing other key information such as previous water additions.

RISER *11 ELEV: $664.53^{\prime}$

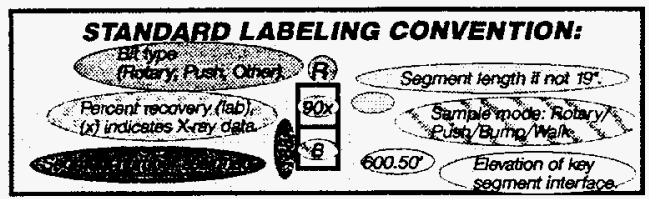

AISER \#14 ELEV: $664.99 '$

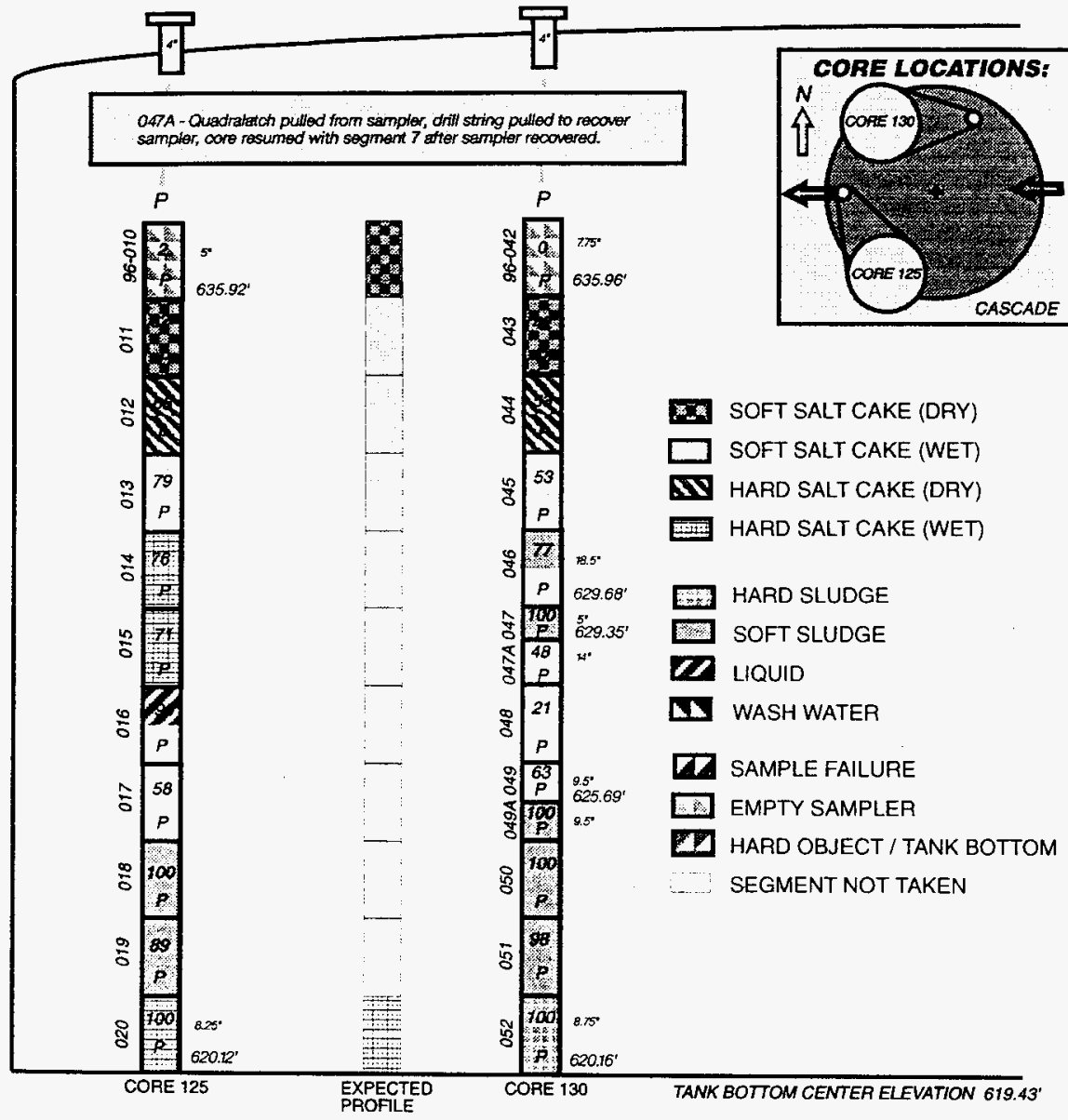




\section{8-110 RMCS CORE PROFILE}

FILE: $\mathbf{5 1 1 0 . C R D}$

DATE: $04 / 24 / 96$

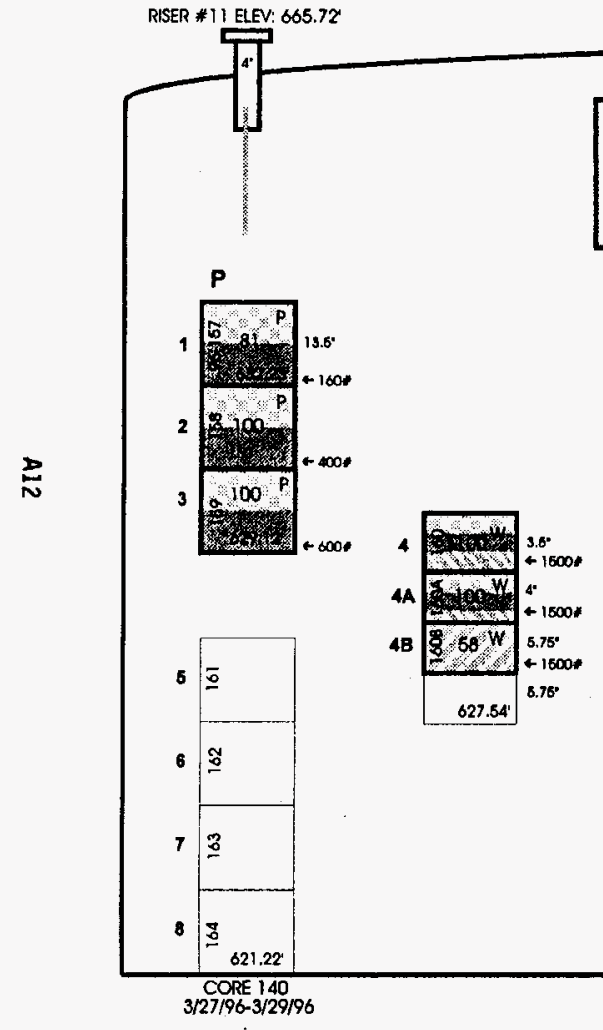

961608 Could not ponebrle waste with
1500 tbs and nepr sheve hatalled.

Profile reflects primary

parameters for each sample.

Data may be adjusted

given information such

as previous water additions.

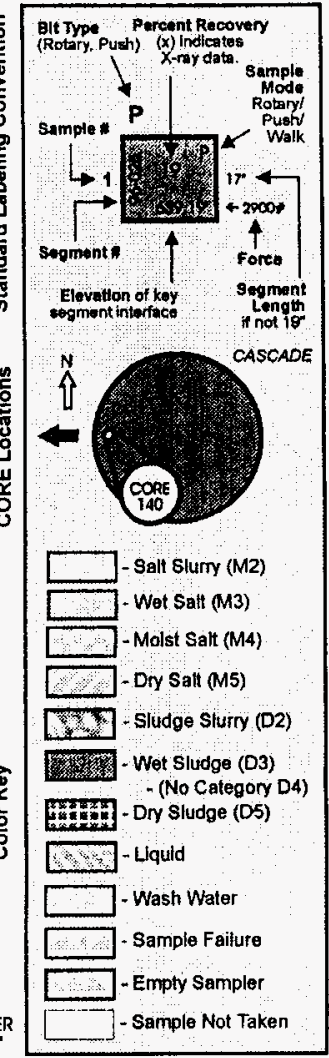




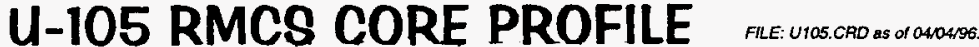

Profiles below indicate primary constituent in sampler and are intended to reflect tank waste conditions. In some instances, extrusion information may be adjusted knowing other key information such as previous water additions.

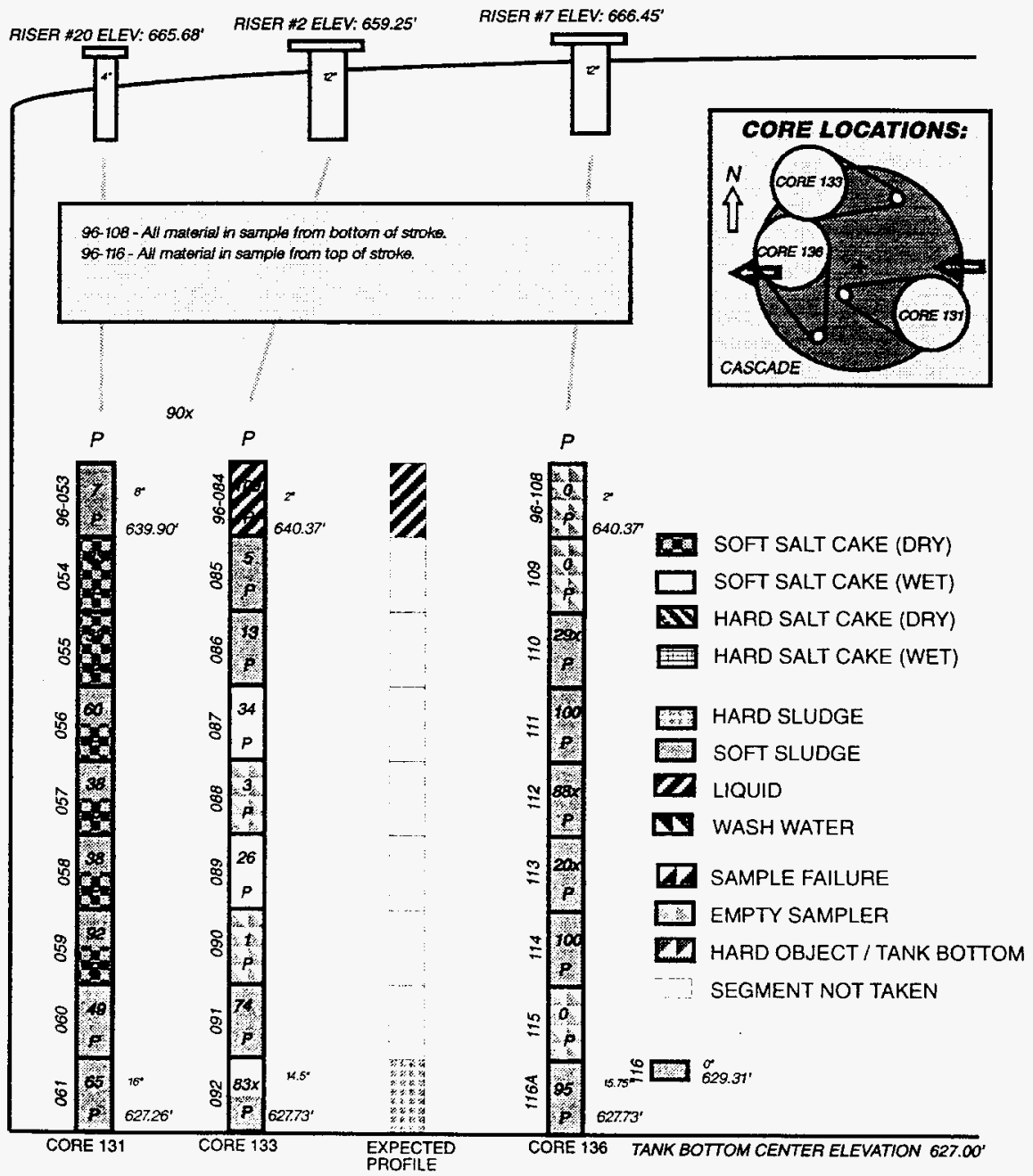

STANDARD LABELING CONVENTION:

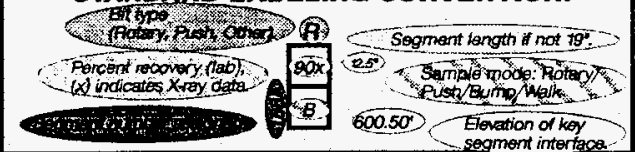

RISER \#7 ELEV: 666.45 


\section{U-107 RMCS CORE PROFILE}

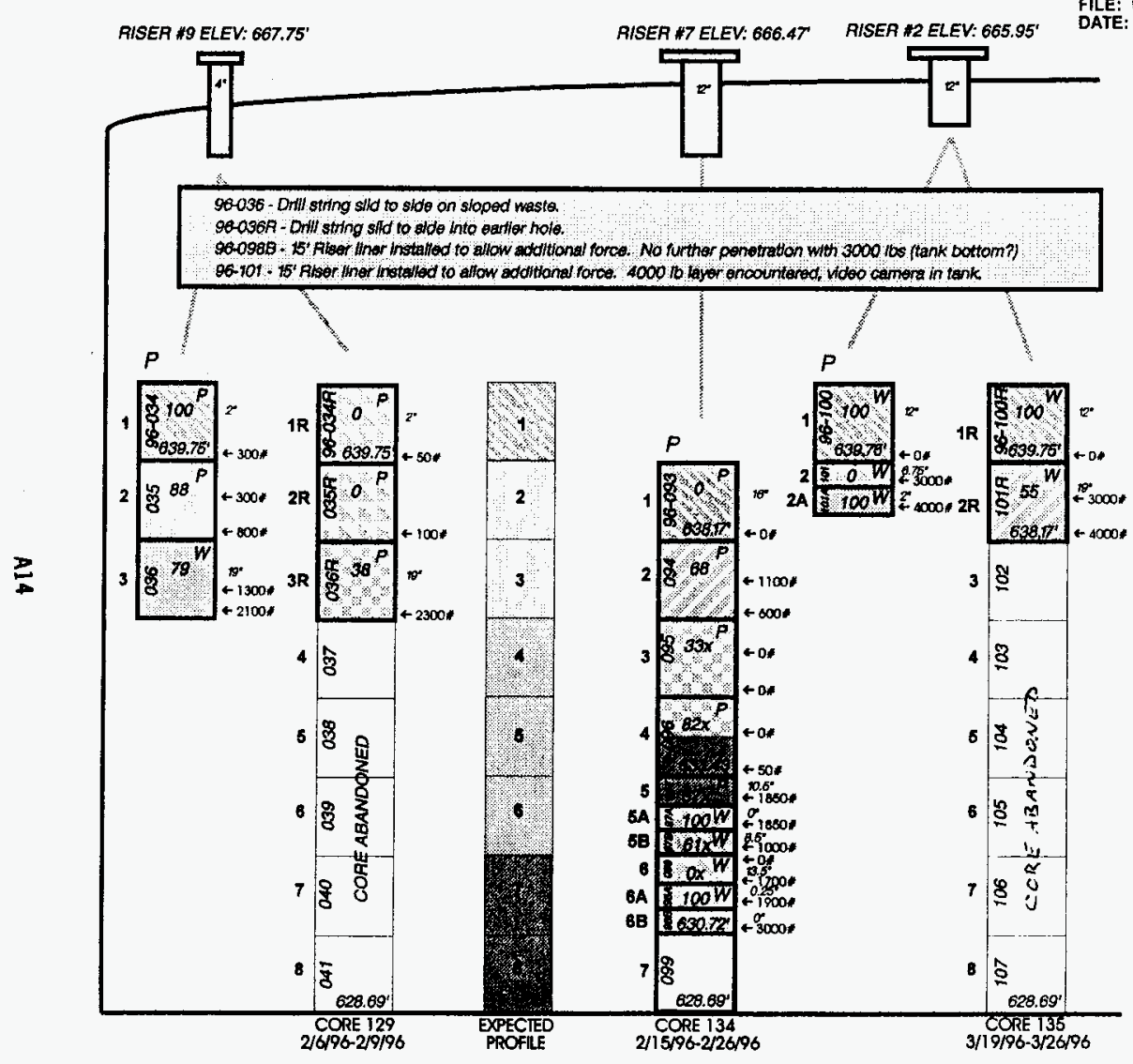

Profile reflects primary

parameters for each sample.

Data may be adjusted

given information such

as previous water additions.

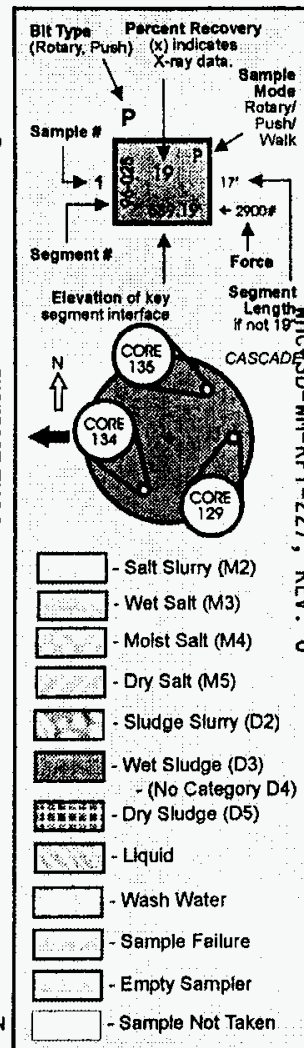




\section{U-109 RMC8 CORE PROFILE}

FILE: U109 CRD

DATE: $04 / 24 / 96$

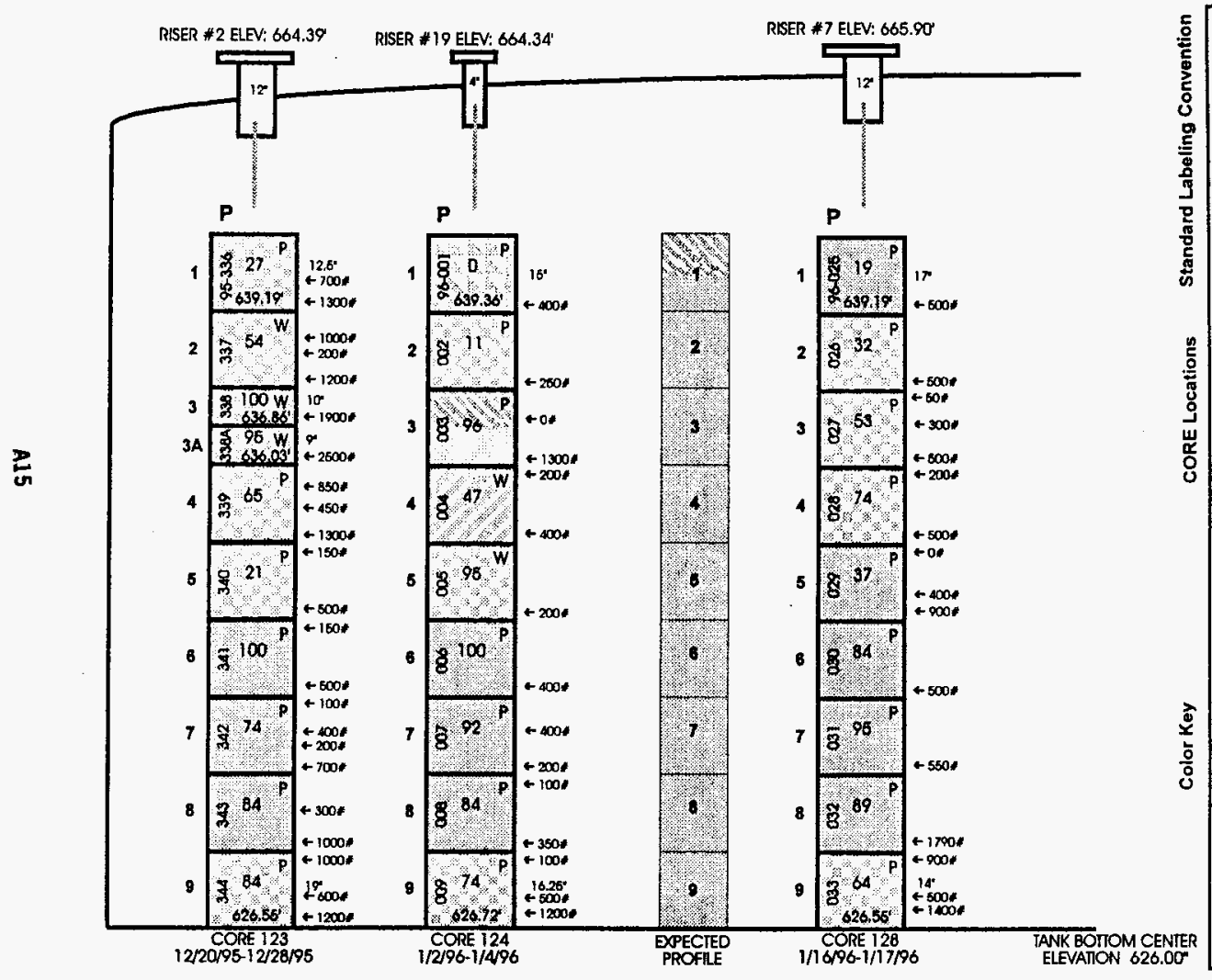

Profile reflects primary

ch sample.

Data may be adjusted

given information such

as previous water additions.

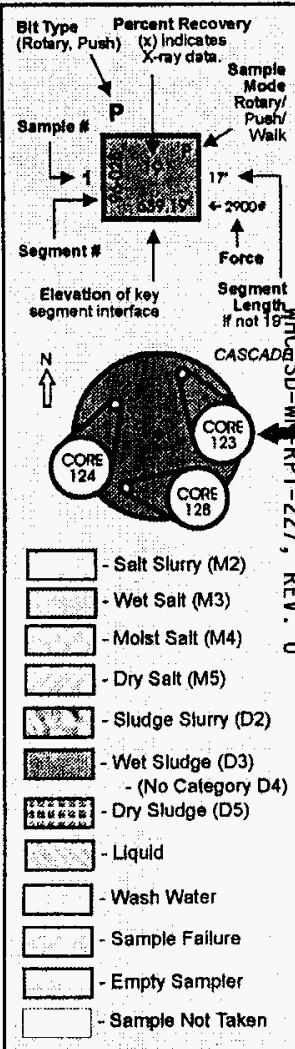




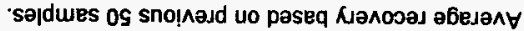

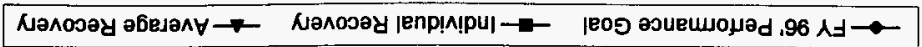

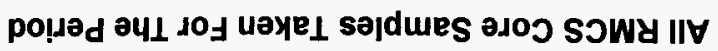

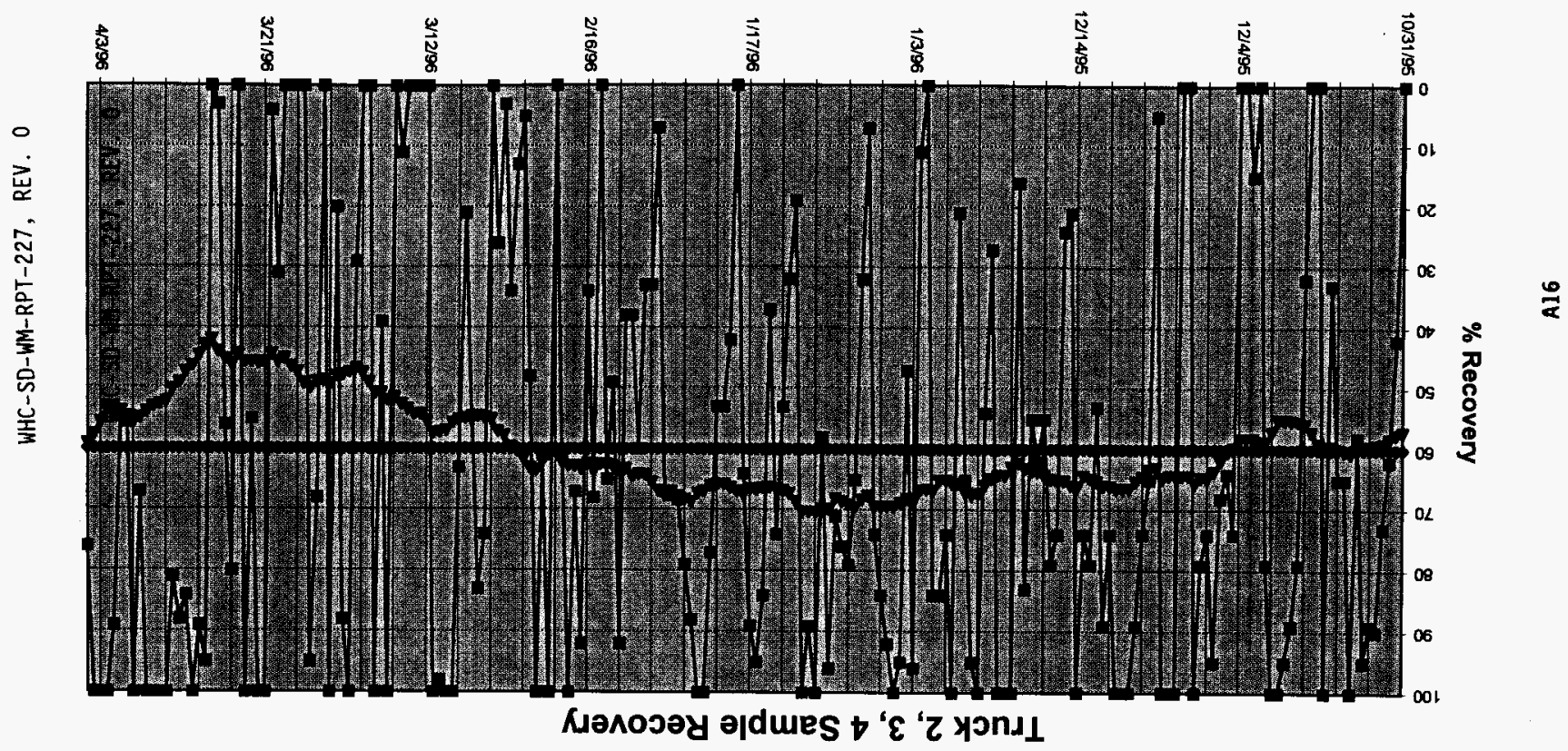


WHC-SD-WM-RPT-227, REV. 0

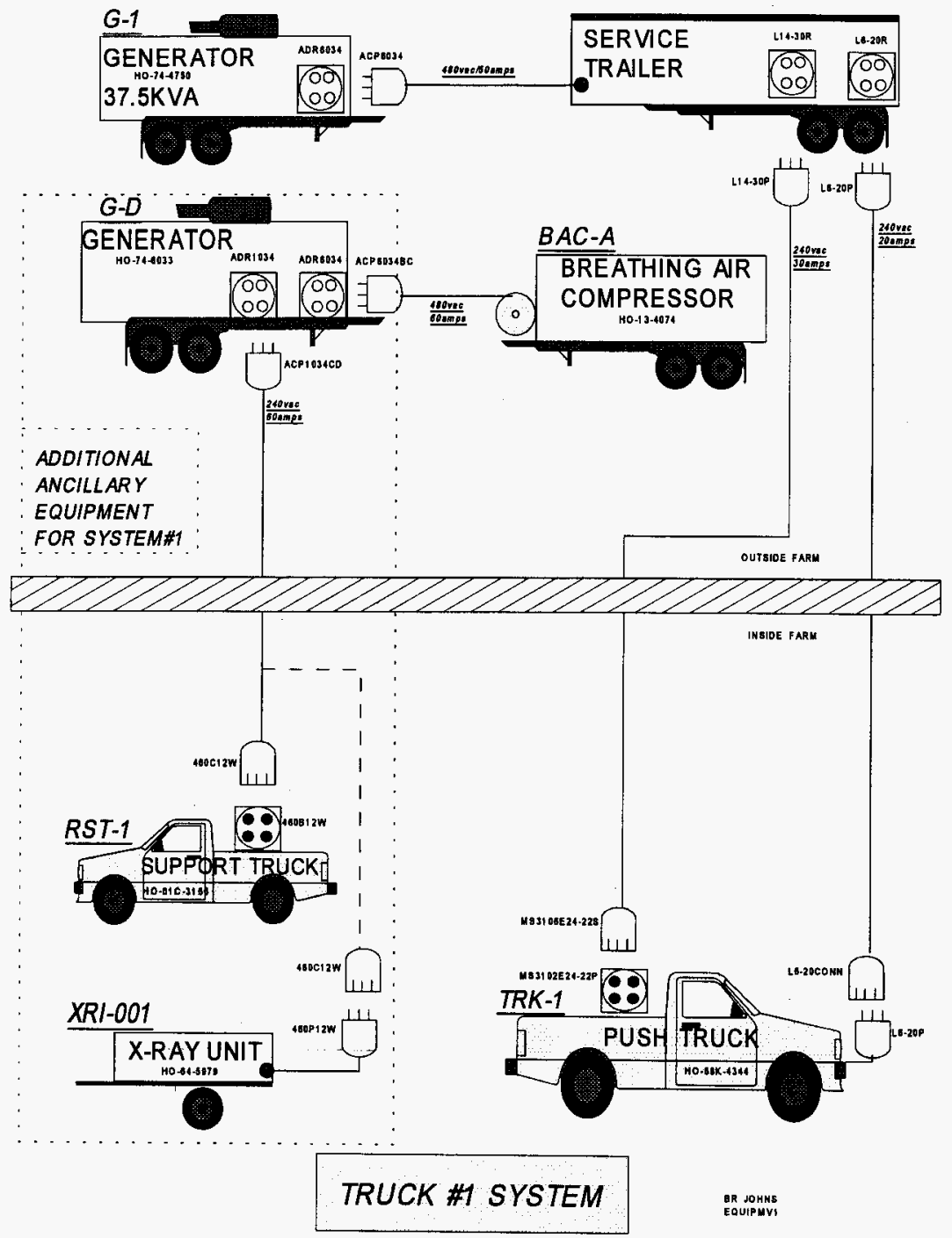




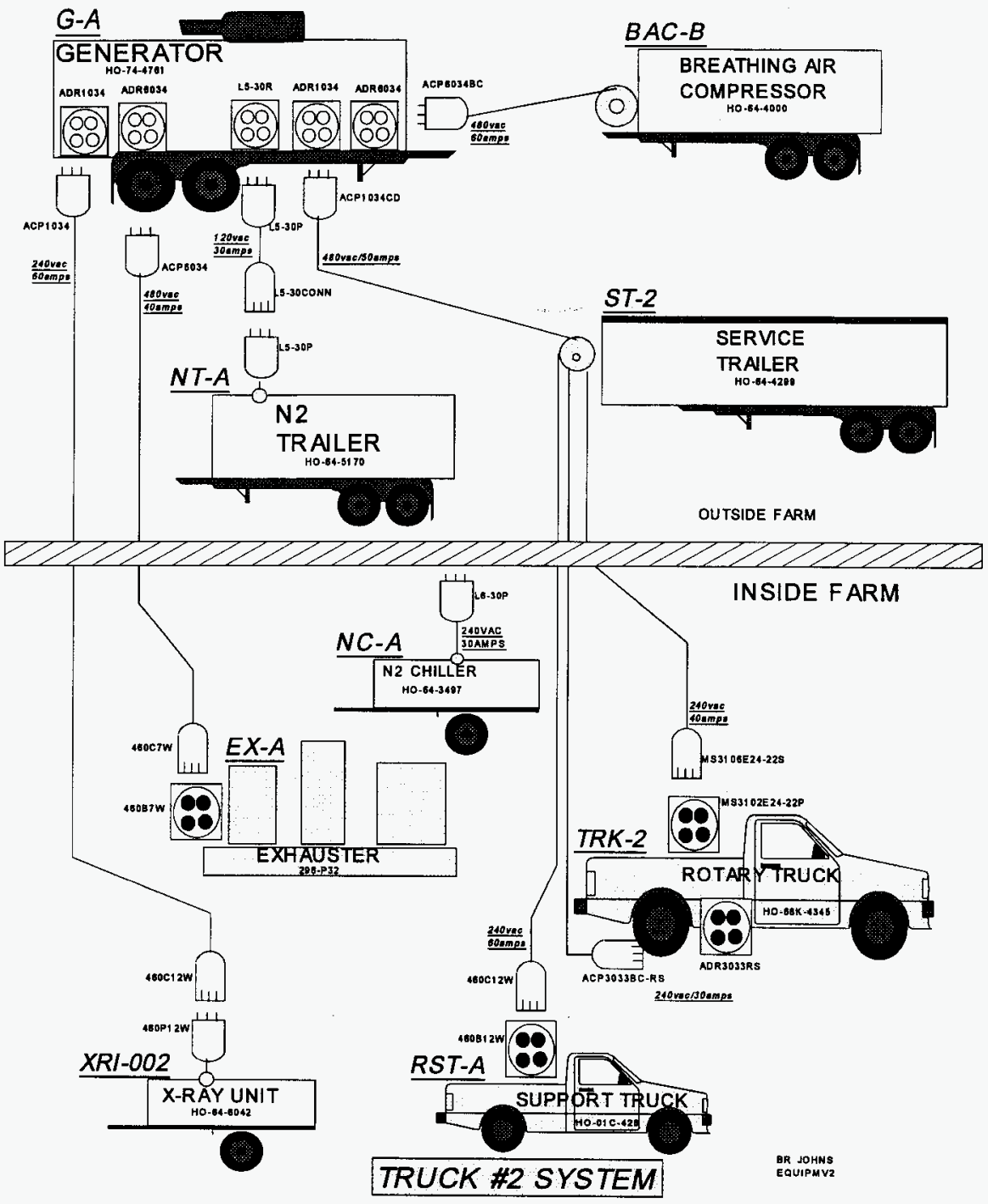


WHC-SD-WM-RPT-227, REV. 0

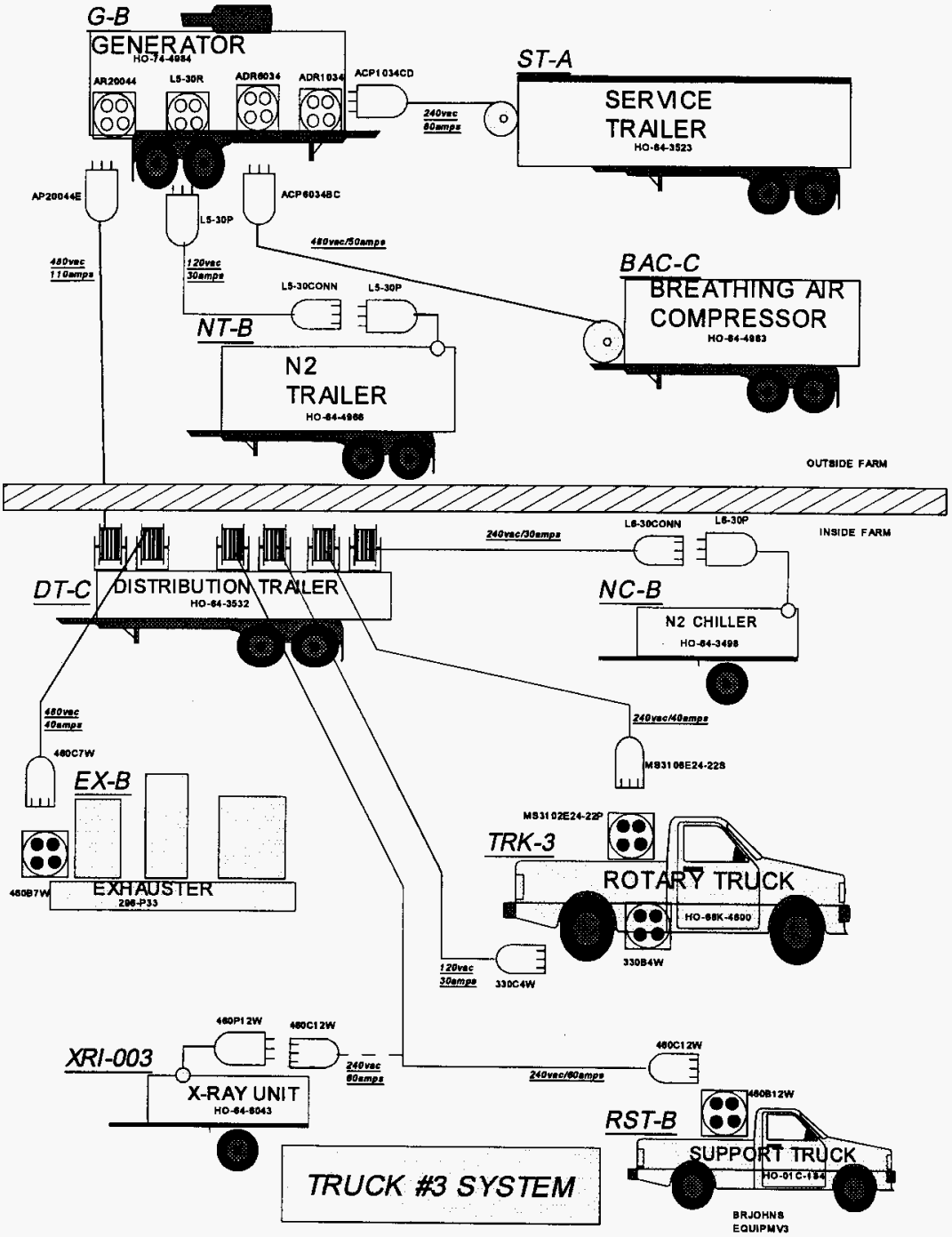


WHC-SD-WM-RPT-227, REV. 0

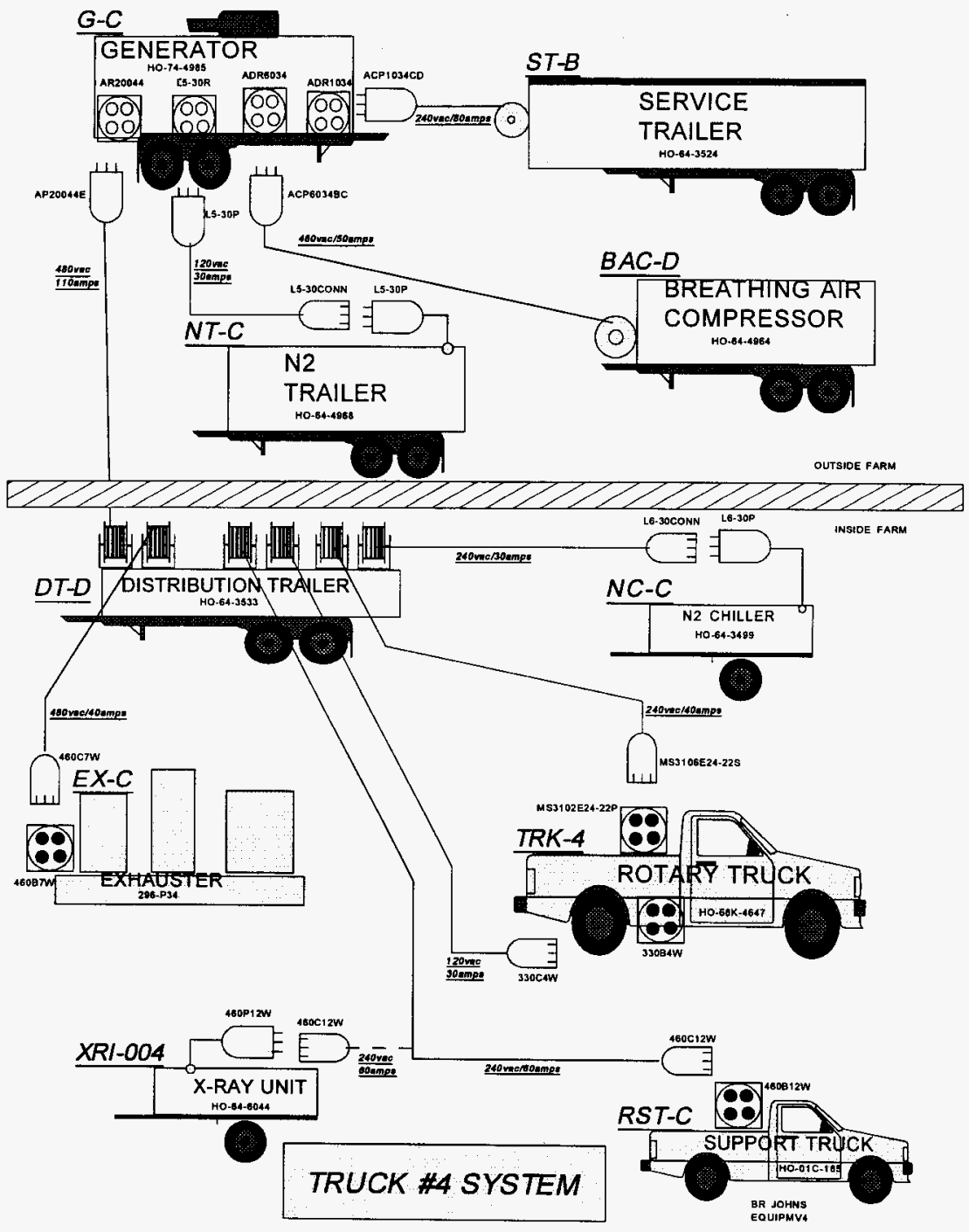


RMCS Truck \#

\begin{tabular}{|c|c|c|c|c|}
\hline Description of Modification & 1 & 2 & 3 & 4 \\
\hline 1. Replace purge gas pressure regulator & $\mathbf{n} / \mathbf{a}$ & next & $3 / 96$ & $4 / 96$ \\
\hline 2. Modify grapple hoist drum & $\mathbf{n} / \mathbf{a}$ & ECN & $3 / 96$ & $4 / 96$ \\
\hline 3. Modify grapple load cell & $\mathbf{n} / \mathbf{a}$ & ECN & $3 / 96$ & $4 / 96$ \\
\hline 4. Modify mechanical counters & ECN & ECN & $3 / 96$ & $4 / 96$ \\
\hline $\begin{array}{l}\text { 5. Modify remote latch unit (RLU) hoist drum spool to } \\
\text { incorporate a cable level-wind system }\end{array}$ & ECN & ECN & *6/96 & *8/96 \\
\hline $\begin{array}{l}\text { 6. Replace current electrical RLU with mechanical } \\
\text { RLU }\end{array}$ & ECN & ECN & *6/96 & ${ }^{*} 8 / 96$ \\
\hline 7. Provide new pendant control & next & next & $6 / 96$ & $8 / 96$ \\
\hline 8. Replace pressure transducers & next & next & $6 / 96$ & $4 / 96$ \\
\hline 9. Install purge gas filter & $\mathbf{n} / \mathbf{a}$ & next & $3 / 96$ & 4/96 \\
\hline 10. Provide bellows on shielded receiver & ECN & ECN & ECN & ECN \\
\hline 11. Econo crane replacement & ECN & ECN & ECN & ECN \\
\hline 12. Replace shielded receiver lifting ramp & ECN & Comp. & Comp. & next \\
\hline 13. Modify platform rotation hydraulics & $\mathbf{n} / \mathbf{a}$ & next & $3 / 96$ & $4 / 96$ \\
\hline
\end{tabular}

* Scheduled with flammable gas modifications.

Next $=E C N$ is complete, ready for next scheduled outage.

$E C N=$ need an ECN or ECN is in signature stage. 
WHC-SD-WM-RPT-227, REV. 0

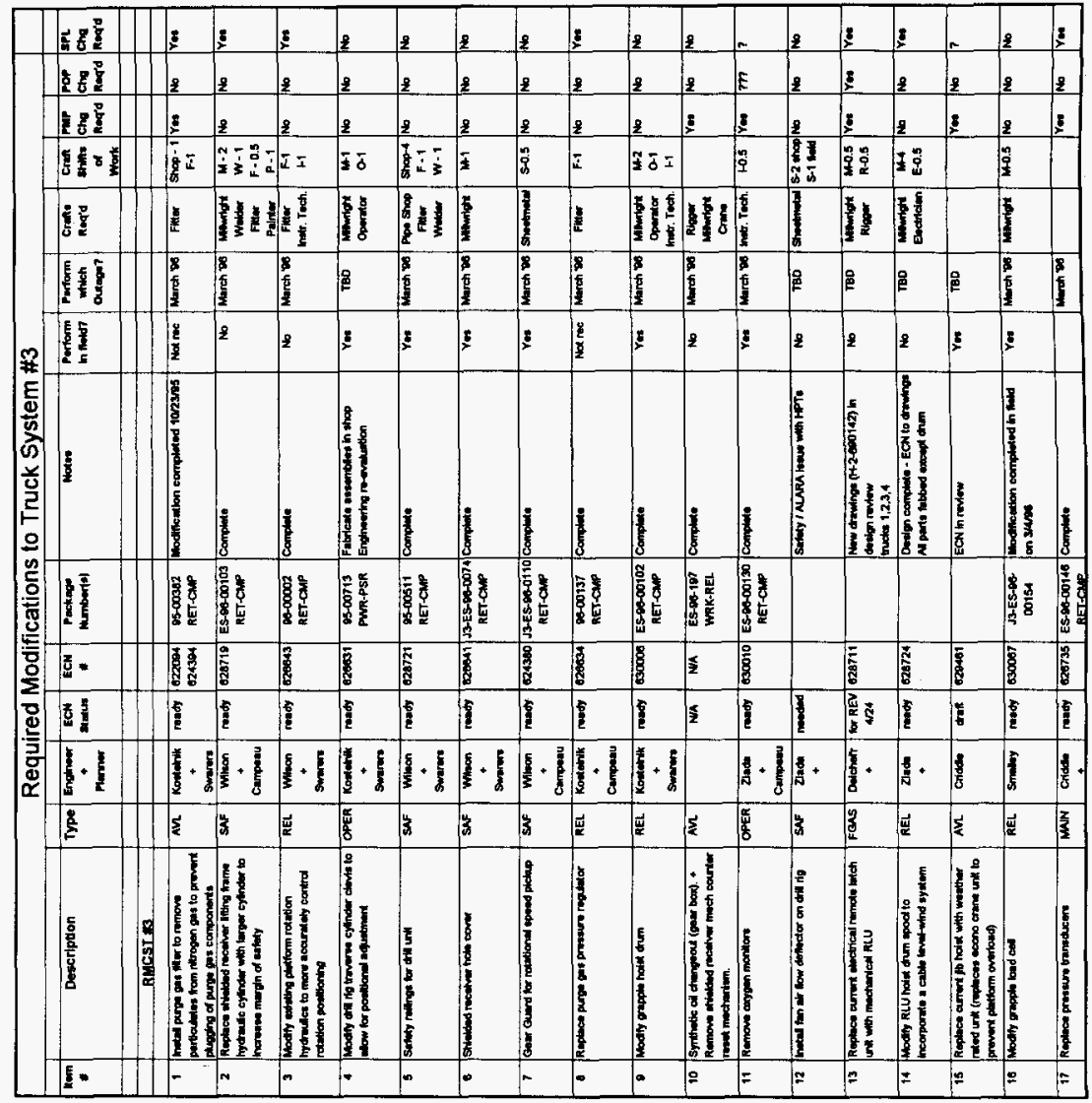


WHC-SD-WM-RPT-227, REV. 0

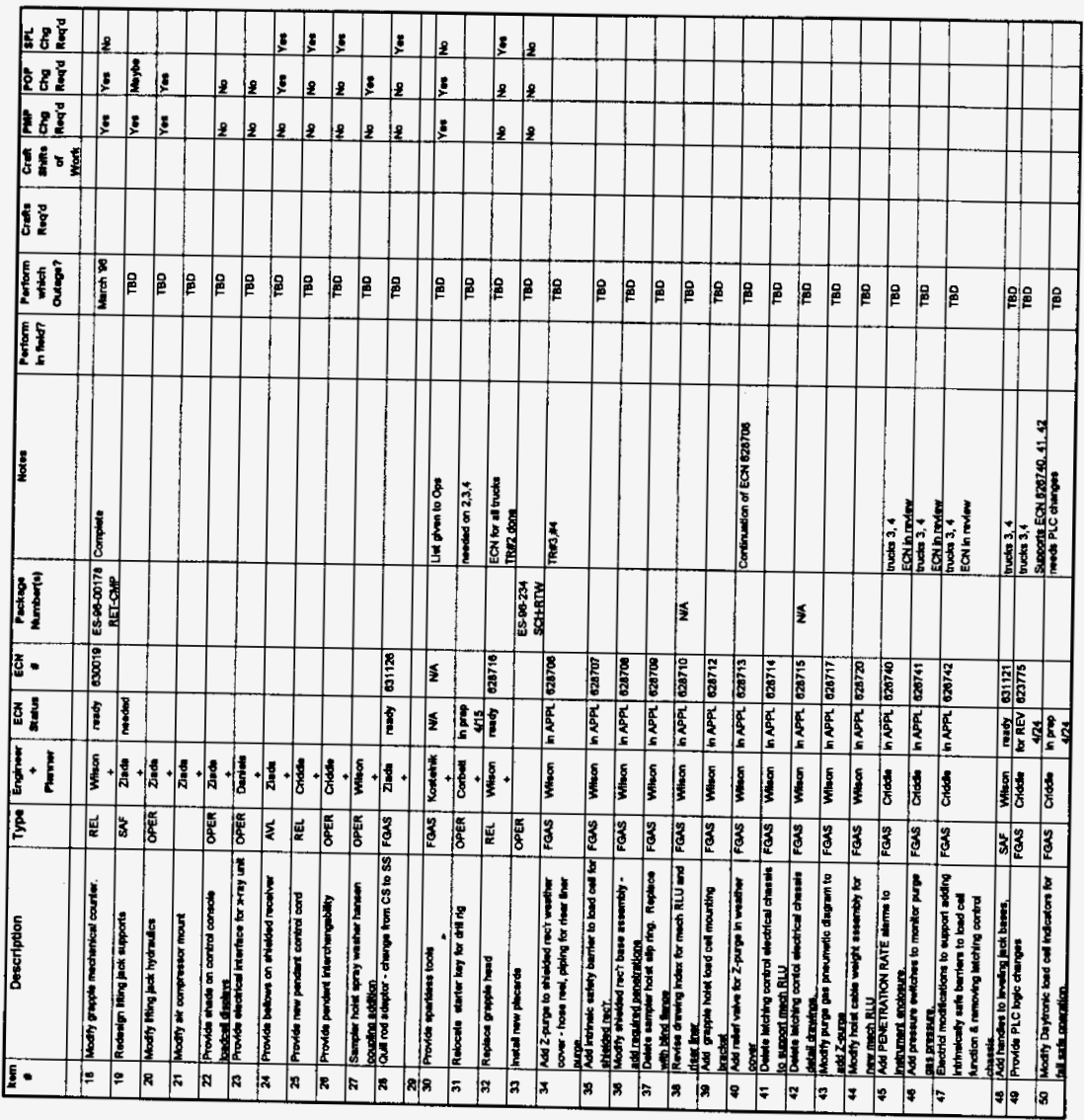


WHC-SD-WM-RPT-227, REV. 0

\begin{tabular}{|c|c|c|c|c|c|c|c|c|c|c|c|c|}
\hline 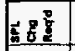 & & & & & $z$ & 5 & & $z$ & & & & \\
\hline$\frac{1}{2}$ & & & $1: E$ & & & & & & & & & \\
\hline$a^{2}$ & & & $\neq: 18$ & $2:$ & & & & & & & & \\
\hline 585 & & & & & & & & & & & & \\
\hline 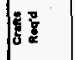 & & & & & & & & & & & & \\
\hline$\frac{6}{2}$ & 奋 & E & 8 & 28 & \begin{tabular}{l|l}
$Q$ & 0 \\
\end{tabular} & 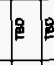 & e & 2 & E 2 & 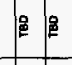 & 促 & e \\
\hline 5 & & & & & & & & & & & & \\
\hline 2 & & 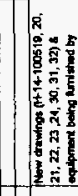 & 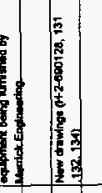 & 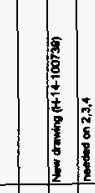 & 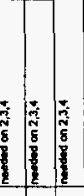 & . & & 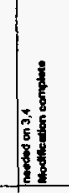 & $\begin{array}{l}-5 \\
5 \\
8 \\
8 \\
8 \\
\end{array}$ & 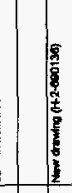 & 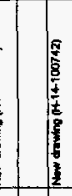 & 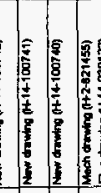 \\
\hline $8 \frac{\bar{g}}{5}$ & & & & 8 & & & & & & & & $=\frac{5}{8}$ \\
\hline 屇: & & 2 & 章 & \begin{tabular}{|l|l|} 
& \\
\end{tabular} & & 㑛 & & 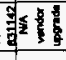 & $8 \frac{8}{8}$ & $\frac{d}{E}$ & & $\Sigma \Sigma$ \\
\hline g & ह & $\Sigma$ & II & $8 \leq$ & $\frac{1}{8}$ & 1 & $\frac{z}{\varepsilon}$ & is & E & E & of & $\Sigma \Sigma$ \\
\hline 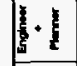 & 8 & 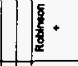 & $\frac{5}{3}+\frac{5}{3}$ & $\frac{1}{3} \cdot \frac{5}{3}$ & $\frac{1}{5}+\frac{1}{3}$. & 1 & $\frac{1}{2}$ & & $5+1$ & & & $+\frac{5}{8}+\frac{5}{2}+\frac{5}{2}$ \\
\hline 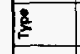 & 馬 & 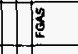 & $\begin{array}{lll}3 & 3 \\
\end{array}$ & $\frac{3}{3}$ & 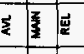 & 8 & 13 & జ & $\frac{z}{2} \leq$ & $\begin{array}{lll}0 \\
\end{array}$ & 3 & $3 \frac{3}{3}$ \\
\hline 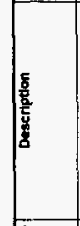 & 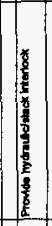 & 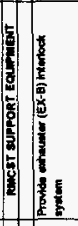 & 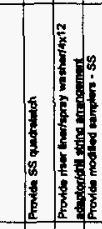 & $\frac{1}{2}$ & 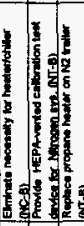 & 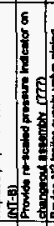 & 政 & 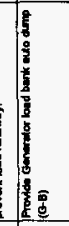 & 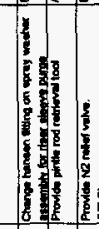 & $\frac{1}{4}$ & $\frac{3}{3}$ & 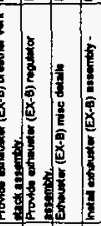 \\
\hline E. & 5 & II- & $\pi 1$ & .1 .5 & -1.0 & $=$ & $E=$ & $=$ & $\pm=1$ & $E=$ & $=: 28$ & $\approx \mathbb{N}$ \\
\hline
\end{tabular}




\section{Distribution of Causes for Sampling Equipment Unavailability}

Fiscal Year 1996 (10/1/95 through 3/15/96)

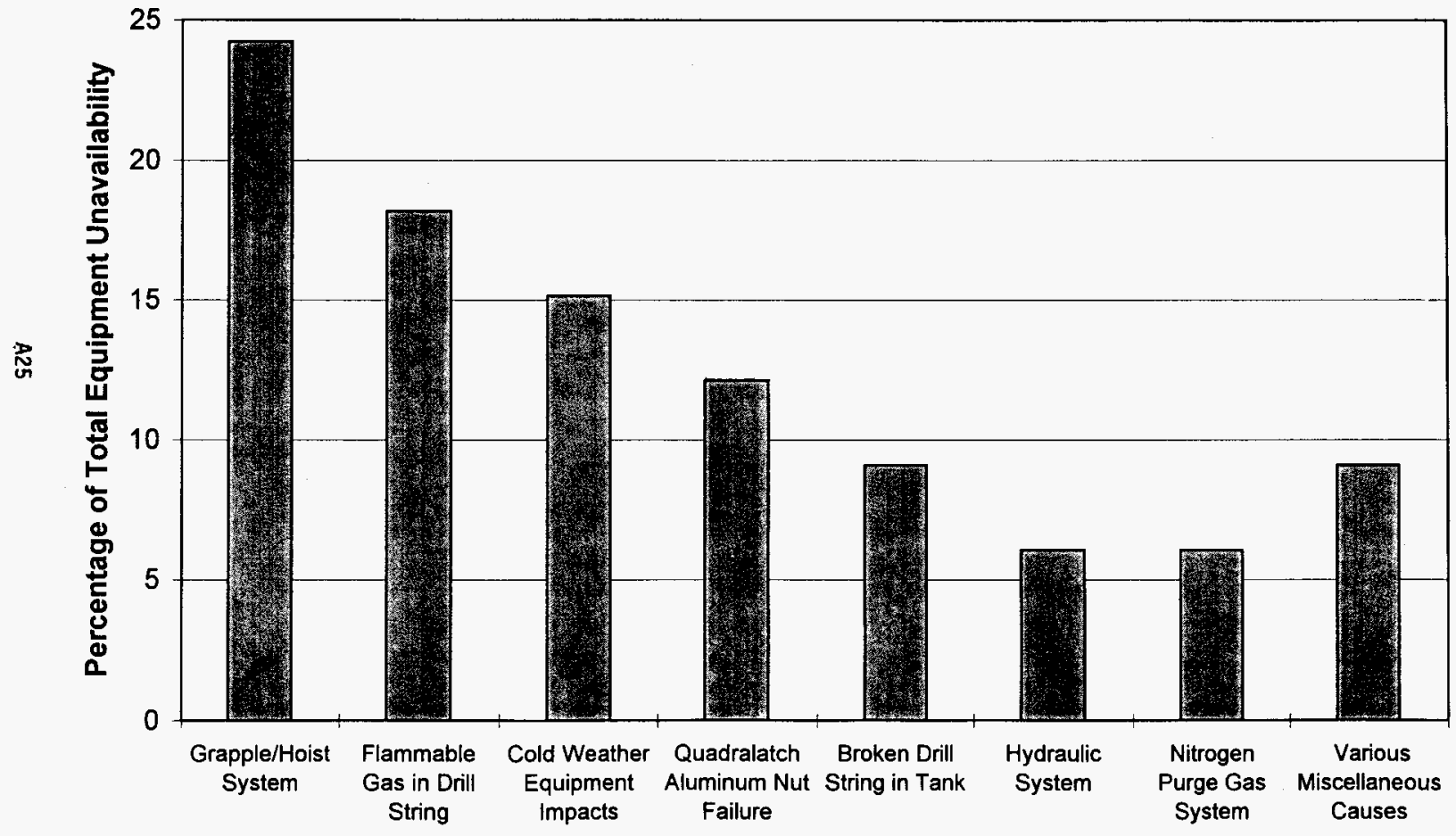




\section{EQUIPMENT MODIFICATIONS PLANNED/IMPLEMENTED}

Grapple/Hoist System

- $\quad$ Revised cable "keeper" system (RMCST \#3 complete)

- $\quad$ Revised cable load cell mount (RMCST \#3,\#4 complete)

- $\quad$ Revised cable payout counter assembly RMCST 3\#,\#4 complete)

- Revised cable drum (planned)

Flammable Gas in Drill String

- Multiple component changes to eliminate sparking capability (push-mode complete, RMCST planned)

- Improved electrical grounding/bonding (complete)

- Revised procedures (complete)

- New sampler bit development/testing (in progress)

Cold Weather Equipment Impacts

- Revised lubricants to eliminate sticking (in progress)

- Revised procedures to assure liquid/condensate line purging (complete)

- $\quad$ Revise procedures to maintain equipment operation within design temperature envelope (complete)

Quadralatch Aluminum Nut Failure

- Revise material to stainless steel for new samplers (complete)

- $\quad$ Revamp existing samplers to stainless steel (in progress)

Broken Drill String in Tank

- Revise procedures to incorporate tank/riser specific push-mode downforce limits (complete)

- Fabricate/deploy riser liner strongbacks for deep cores (complete)

Hydraulic System

Replace pressure transducers with calibrateable units (RMCST \#3 complete)

- - Revise-platform rotation hydraulic-control (RMCST \#3 completel

N2 Purge Gas System (in progress)

- $\quad$ Revise piping for valve orientation \& pressure relief

- Replace propane heater with ambient evaporation type 


\section{Core Sampling Systems Availability (FY1996)}

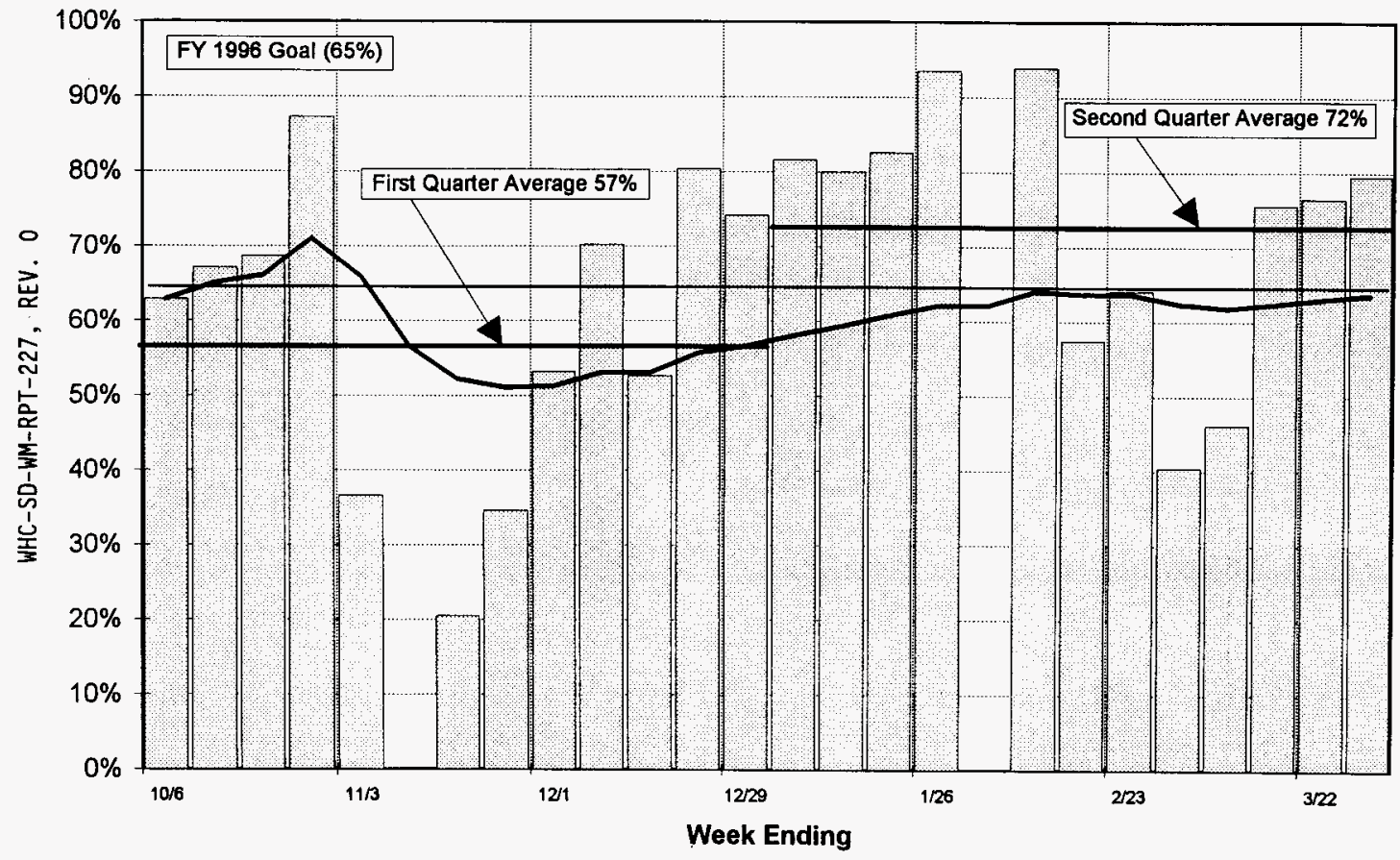

$\square$ Weekly Average - Cumulative Average




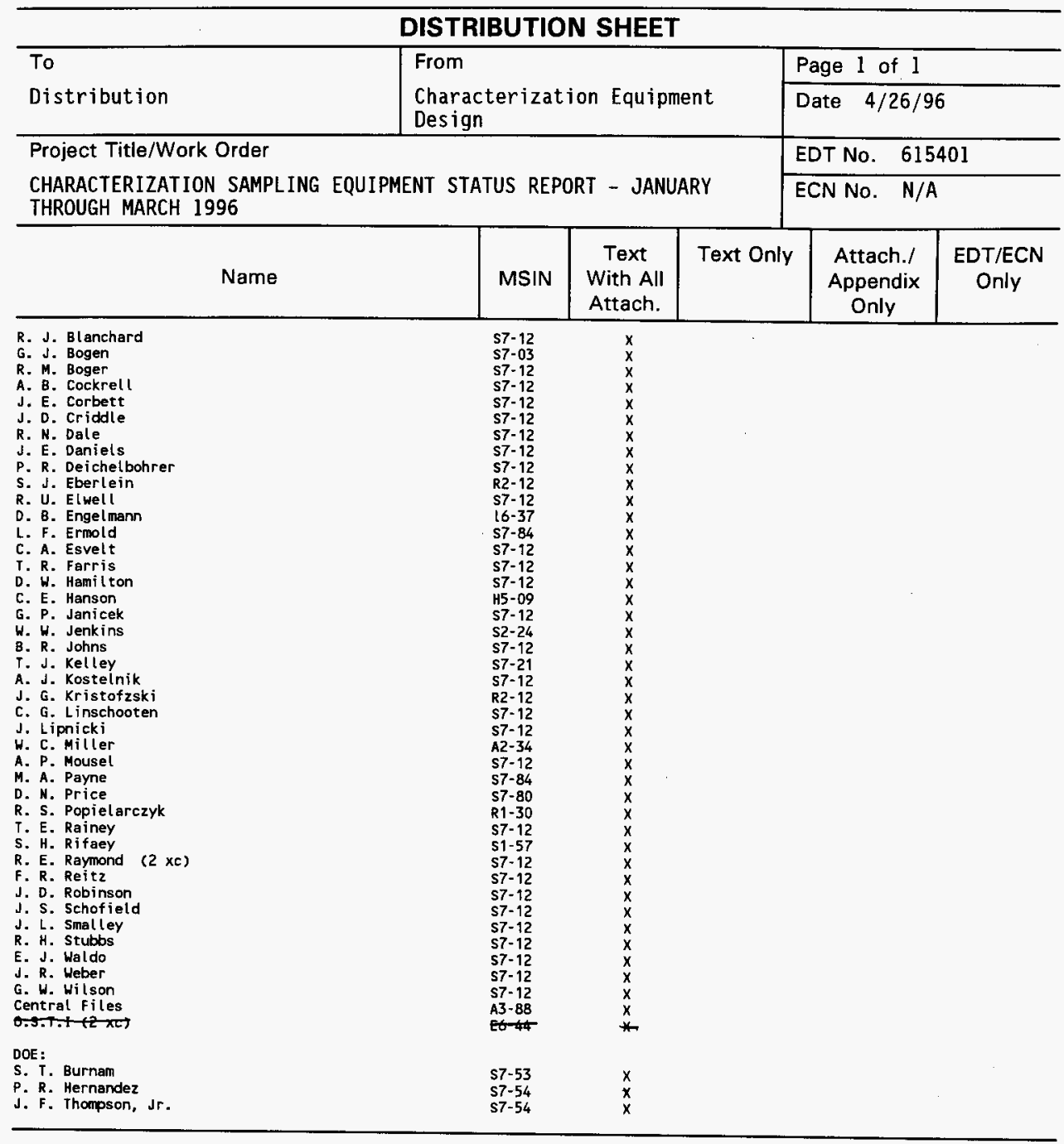

